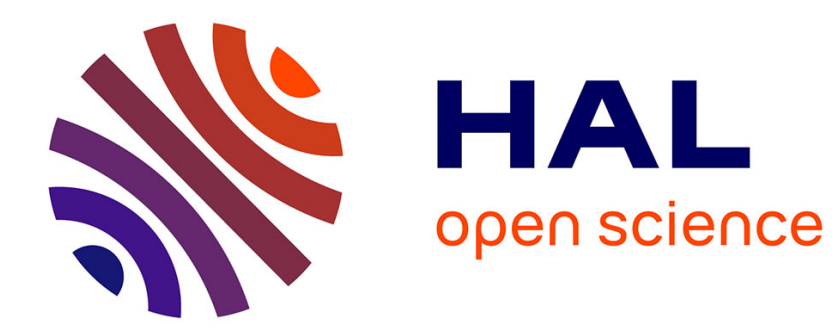

\title{
Roles of FGF Receptors in Mammalian Development and Congenital Diseases
}

Xavier Coumoul, Chu-Xia Deng

\section{To cite this version:}

Xavier Coumoul, Chu-Xia Deng. Roles of FGF Receptors in Mammalian Development and Congenital Diseases. Birth Defects Research Part C: Embryo Today: Reviews, 2003, 69 (4), pp.286-304. 10.1002/bdrc.10025 . hal-02171887

\section{HAL Id: hal-02171887 \\ https://hal.science/hal-02171887}

Submitted on 3 Jul 2019

HAL is a multi-disciplinary open access archive for the deposit and dissemination of scientific research documents, whether they are published or not. The documents may come from teaching and research institutions in France or abroad, or from public or private research centers.
L'archive ouverte pluridisciplinaire HAL, est destinée au dépôt et à la diffusion de documents scientifiques de niveau recherche, publiés ou non, émanant des établissements d'enseignement et de recherche français ou étrangers, des laboratoires publics ou privés. 


\section{Roles of FGF receptors in mammalian development and congenital diseases}

Xavier Coumoul and Chu-Xia Deng*

Genetics of Development and Disease Branch, Digestive and Kidney Diseases, National Institutes of Health, 10/9N105, 10 Center Drive, Bethesda, MD 20892, USA.

Phone: 301-402-7225, Fax: 301-480-1135

Email: chuxiad@bdg10.niddk.nih.gov

${ }^{*}$ Author for correspondence

Key words: FGF receptors, skeletal dysplasia, mouse models, development, cancer 


\begin{abstract}
Four fibroblast growth factor receptors (FGFR1-4) constitute a family of transmembrane tyrosine kinases that serve as high affinity receptors for at least 22 FGF ligands. Gene targeting in mice has yielded valuable insights into the functions of this important gene family in multiple biological processes. These include mesoderm induction and patterning, cell growth, migration and differentiation, organ formation and maintenance, neuronal differentiation and survival, would healing and malignant transformation. Furthermore, discoveries that mutations in three of the four receptors result in more than a dozen human congenital diseases highlight the importance of these genes in skeletal development. In this review, we will discuss recent progress on the roles of FGF receptors in mammalian development and congenital diseases with an emphasis on signal transduction pathways.
\end{abstract}




\section{Introduction}

\section{Properties of the FGF family}

The first fibroblast growth factor (FGF) was identified in 1974 (Gospodarowicz, 1974). Since that date, 22 distinct FGFs have been characterized in various invertebrates and vertebrates (Coulier et al., 1997; Ornitz and Itoh, 2001). They are notably involved in development and homeostasis.

Most orthologous FGFs are highly conserved. Their gene locations on the chromosomes indicate that the different members have been generated by genome-duplication and gene-translocation mechanisms that occurred during the emergence of vertebrates (Coulier et al., 1997). The FGFs can be classified in subgroups depending on their amino acid sequence homology (for example in humans: FGF9, 16 and 20 or FGF8, 17 and 18 display more than 70\% identity) (Ornitz and Itoh, 2001).

Almost all tissues express FGFs. The profile of expression is often similar within the same subgroup (Maruoka et al., 1998). Their mode of action is highly variable: most FGFs are secreted even if some of them lack signal sequences (FGF 9, 16, 20). Some FGFs remain intracellular (FGF 11-14) or are sequestered by the extracellular matrix (FGF 1-2). FGF 2 and 3 contain nuclear-localization signals but no function of these proteins in the nucleus has been found. Timing of expression also varies; for instance, some FGFs are only expressed during embryonic development, such as FGF 3, 4, 8, 15, 17 and 19.

The molecular weight of vertebrate FGFs is comprised between 17 and 34 $\mathrm{kDa}$. They form polypeptides with a dominance of $\beta$-strands forming $\beta$-sheets (Eriksson et al., 1991). Notably, they all share a core domain containing 
conserved structural motifs implicated in interaction with their high affinity receptors (FGFRs), (membrane protein tyrosine kinases) (Martin, 1998; Plotnikov et al., 2000; Xu et al., 1999)

\section{Properties of FGF Receptors}

Since the first identification of a FGF receptor in the mid-80s (Lee et al., 1989; Olwin et al., 1986), four FGF receptors (FGFR 1-4) have been characterized ${ }^{1}$. They contain two or three immunoglobin-like (Ig) domains and a heparinbinding sequence (Fig. 1). Alternative splicing of FGFR1, FGFR2 and FGFR3 generates several isoforms due to the alternative splicing event in the exons encoding the carboxyl-terminal half of IgIII. The most well studied isoforms are FGFR2b and FGFR2c, which exhibit exquisitely specific ligand-binding properties, and are also regulated in a tissue-specific manner. FGFR2b expression is restricted to epithelial lineages and FGFR2c expression is mainly in mesenchymal lineages (Orr-Urtreger et al., 1993; Xu et al., 1998; Yu et al., 2000). It has been shown that FGF ligands and receptors interact in a paracrine fashion, i.e. the mesenchymally expressed ligands, FGF7 and FGF10, can activate only FGFR2b, whereas the epithelium based ligands, FGF2, FGF4, FGF6, FGF8, and FGF9 are specific for FGFR2c (Orr-Urtreger et al., 1993; Xu et al., 1998; Yu et al., 2000).

The heparin-binding domains of the receptors are responsible for the formation of a complex between low affinity receptor, heparin or heparan sulfate, and ligands (FGF). Heparin or heparan sulfate is essential for a complete 
activation of FGF pathways (Ornitz, 2000). After stimulation, FGF-FGFR complexes internalize and could trigger other transduction pathways in the nucleus and perinuclear structures. This mechanism could involve a delivery of FGF to other intracellular targets (Maher, 1996; Peng et al., 2001; Reilly and Maher, 2001; Stachowiak et al., 1997; Stachowiak et al., 1996; Stachowiak et al., 1996; Wiedlocha et al., 1994; Wiedlocha et al., 1995) but none of them have been identified.

The pattern of expression of the receptors during development is important in regard to mediating FGF actions in a tissue specific fashion (OrrUrtreger et al., 1991):

Fgfr1, which is expressed almost exclusively in the mesenchyme ${ }^{2}$, plays an essential role during early stages of development (for instance, mesoderm patterning and cell migration during gastrulation) and at several levels during organogenesis.

- On the contrary, Fgfr2 is mainly detected in the epithelial lineages during early gastrulation. During organogenesis and later development, it is expressed in both epithelial and mesenchymal cells, mediating a paracrine loop between mesenchyme and epithelium based FGF ligands. For instance, a mutation of this receptor uncoupled the reciprocal regulation loop between FGF8 and FGF10, leading to the failure of limb induction (see below).

Fgfr3 is mostly expressed in the central nervous system and bone

\footnotetext{
${ }^{1}$ A potential FGF receptor, FGFR5, was described by two independent studies (Kim et al., 2001; Sleeman et al., 2001). Because the characterization is still preliminary, it will not be reviewed here). This receptor lacks intracellular kinase domain.
} 
rudiments. As a consequence, mutations of human FGFR3 (and also FGF23, a potential ligand) affect growth of the limb bones (leading to syndromes called achondroplasia, hypochondroplasia, thanatophoric dysplasia or SADDAN syndromes (see below). Mouse models have shown that Fgfr3 is a negative regulator of bone growth and development. Finally, Fgfr4 is detected in the definitive endoderm and the somatic myotome and cooperates with Fgfr3 to control postnatal lung development and liver functions.

The importance of FGFRs is detailed below in regard of their roles in embryogenesis, development and organogenesis:

\section{Roles of FGFRs in mammalian development revealed by loss of function mutations}

In order to study functions of FGF receptors, mouse strains carrying many different types of mutations, null, hypomorphic, isoform or conditional, have been introduced into FGF receptors using gene targeting (Table 1). Analysis of these mutant mice has provided valuable information about FGF receptors in various aspects of mammalian development.

\section{Gastrulation}

Targeted disruption of Fgfr1 in mouse resulted in recessive embryonic lethality during gastrulation (Deng et al., 1994; Yamaguchi et al., 1994). Mutant

${ }^{2}$ Mesenchyme: embryonic tissue that is composed of loosely organized unpolarized cells of both mesodermal and ectodermal origin, with a proteoglycan-rich extracellular matrix 
embryos were developmentally retarded, exhibiting disorganization of axial mesoderm and defective development of the posterior structures (Deng et al., 1994; Yamaguchi et al., 1994). Analysis of chimeric embryos formed between wild type embryos and mutant embryonic stem (ES) cells revealed accumulation of mutant cells in the posterior regions, presumably due to retarded migration of mesoderm precursors across the primitive streak (Ciruna et al., 1997; Deng et al., 1997), a process that may involve relay-proteins like Shp2 and Src (Liu et al., 1999; Saxton et al., 2000) and the MAPK pathway (Curran and Grainger, 2000). In wild type embryos, mesodermal cells at the primitive streak undergo epithelialmesenchymal transformation (EMT), which correlates with downregulation of Ecadherin. This process, however, is not observed in Fgfr1-/- embryos. Their further analysis indicated that the prolonged expression of E-cadherin (due to the lack of mSnail, an E-cadherin repressor) sequestered membrane bound $\beta$ catenin, and attenuated Wnt3a signaling and T-box transcription factor expression, leading to the reduction of several mesodermal structures and formation of ectopic neural tubes (Ciruna and Rossant, 2001).

\section{Organogenesis}

\section{Limb induction and morphogenesis}

The roles of FGF/FGFR signaling in limb formation have been most intensively studied. Several FGFs are expressed at varying phases of limb development with distinct patterns (Capdevila and Izpisua Belmonte, 2001; Martin, 1998; Niswander, 2002; Tickle and Munsterberg, 2001). During early stages prior to apical ectodermal ridge (AER) induction, Fgfr1 is expressed in the limb mesenchyme whereas Fgfr2 is present in the limb ectoderm and the 
underlying mesenchyme. After induction, Fgf4, 8, 9, 19 and Fgfr2b are expressed in AER whereas Fgf10 and Fgfr2c are detected in the underlying mesenchyme. It was shown that excision of the AER resulted in truncation of limb. This defect could be overcome by embedding beads containing Fgf2 and Fgf4 in mesenchyme of the limb bud (Martin, 1998; Niswander and Martin, 1992; Tickle and Munsterberg, 2001). This observation indicates an essential role of the AERsecreted FGFs in limb bud outgrowth.

Because Fgfr1-null embryos died at stages prior to limb induction, chimeric embryos were used to assess its role during limb development (Deng et al., 1997). This study revealed that Fgfr1 deficiency might not block limb bud initiation, as even high degree chimeric embryos could initiate limb formation. However, at E10.5, FGFR1-deficient cells were excluded from the distal mesenchyme and preferably populated ectoderm and AER. At E11.5-E12.5, all chimeric limb buds were developmentally retarded, and exhibited abnormal shape and rough surface. Their further study in embryos deficient for the full-length isoform of Fgfr1 confirmed essential roles of this gene in distal mesoderm patterning and digit formation (Xu et al., 1999).

To study a role of Fgfr2 in limb development, Xu et al. (1998) deleted both Fgfr $2 b$ and Fgfr2c isoforms and found that the mutant embryos Fgfr2 ${ }^{\Delta I I I / \Delta I I I}$ embryos (rescued by a tetraploid embryo fusion approach) were limbless due to a failure in limb induction ( $\mathrm{Xu}$ et al., 1998). The presumptive limb territory showed initial thickening but Fgf8 was not detected in the ectoderm and Fgf10, which was initially expressed in the mesenchyme, gradually disappeared. Based on their findings, they proposed that limb induction is dependent on a positive 
regulatory loop involving several Fgfs and the two isoforms of Fgfr2. According to this model, Fgf10 secreted by the underlying distal mesenchyme activates Fgfr2b, the ectodermal isoform. This leads locally to an increase expression of Fgf8, which, after diffusion to the underlying mesenchyme, increases the expression of Fgf10 by activating the mesenchymal Fgfr2c (Xu et al., 1998).

Fgfr2b and Fgfr2c were also disrupted separately by gene targeting. The absence of Fgfr2b or Fgfr2c alone did not block limb bud initiation (Eswarakumar et al., 2002; Revest et al., 2001). Fgfr2b deficient limb bud still expressed Fgf8 at initiating stages, and number of other genes important for limb bud outgrowth, such as Bmp4 and Msx1, however, it failed to express Sonic Hedgehog (Shh) and Fgf4. Moreover, in the absence of FgfR2b, extensive apoptosis of the limb bud ectoderm and mesenchyme occurred between E10 and E10.5, providing evidence that Fgfr2b-mediated Fgf signals act primarily as survival factors for limb bud maintenance and growth (Revest et al., 2001). In contrast, disruption of Fgfr2c alone did not have an obvious effect on limb development (Eswarakumar et al., 2002), suggesting its absence could be compensated, perhaps by other unidentified mesenchymal based splicing isoforms of Fgfr2 and/or Fgfr1.

\section{Epidermal development}

FGF signaling is important for epidermal development and wound healing. They serve as mitogenic stimulators of epidermal keratinocytes, dermal fibroblasts and endothelial cells (Clement-Lacroix et al., 1991; Ristow and Messmer, 1988; Suhardja and Hoffman, 2003). A number of FGFs and their 
receptors are differentially expressed in the ectoderm and underlying mesenchyme and function in a reciprocal interacting loop that specifies skin development (Werner et al., 1992; Werner et al., 1993). It was shown that both Fgfr2b-/- and Fgfr2 III/ III deficient embryos displayed abnormal skin (De Moerlooze et al., 2000; Li et al., 2001). Analyzing Fgfr2 ${ }^{\Delta I I I / \Delta I I I}$ embryos, Li et al. (2001) demonstrated that the Fgfr2 ${ }^{\text {IIII/ } / I I I}$ mutation blocked skin formation during early stages of skin development due to inhibiting keratinocyte proliferation (E11-E13) (Li et al., 2001). However, Fgfr2-independent skin formation occurred in E14.5 mutant embryos, resulting in a much thinner, yet well-differentiated epidermis. Mutant skin remained thin with decreased hair density after transplantation to wild-type recipients. These observations reveal an essential role of Fgfr2 in skin formation and patterning. Their data also revealed that FGFs and receptors have a similar pattern of expression during eye lid development and the Fgfr2 ${ }^{\text {IIII/AIII }}$ mutation blocked eye lid formation (Li et al., 2001).

\section{Lung development}

Expression studies revealed that all four receptors are expressed in lung with Fgfr1 primarily in mesenchyme and Fgfr2 mainly restricted in epithelium (Orr-Urtreger et al., 1991; Peters et al., 1992; Weinstein et al., 1998). Fgfr2 mouse embryos did not have a lung when analyzed at the earliest stages of lung formation, indicating that this receptor is responsible for lung induction ( $\mathrm{Li}$ et al., 2001). In contrast, targeted disruption of the full length isoform of Fgfr1 did not block lung initiation although mutant lung was significantly smaller than control 
(Xu et al., 1999; and our unpublished data). Embryos missing each of Fgfr3 or Fgfr4 displayed no lung phenotype during all stages of development (Deng et al., 1996; Weinstein et al., 1998). However, in the Fgfr3 and Fgfr4 double mutants, even if the lungs were perfectly normal at birth, the alveogenesis process was impaired in later development, lending to breathing difficulty and death of these mutant mice. Surfactant expression was normal but postnatal downregulation of elastin was impaired. Thus, these two receptors cooperate to direct alveogenesis in murine lung (Weinstein et al., 1998).

\section{Central nervous system (CNS)}

FGF signaling plays an important role in CNS development and is involved in numerous processes including proliferation, migration and survival of neurons and glial cells. The four FGFRs are expressed in the CNS with FGF2, 8, 15 and 17 among their most important ligands (Ford-Perriss et al., 2001). Mouse and chick models have shown that FGFR1 is broadly expressed whereas FGFR2 and FGFR3 are also detected in specific regions (Mason et al., 2000; Walshe and Mason, 2000). FGFR4 is not present in adult mouse brain analyzed by northern blot analysis (Weinstein et al., 1998).

FGFRs play an important role during neural induction, as shown by experiments with dominant negative forms in Xenopus (Launay et al., 1996). During early and mid-phases of neurogenesis, Fgfr1 and Fgfr2 are expressed at high levels. In chimeric mouse embryos, Fgfr1-/- progenitor cells could form neural tubes; however they exhibited defects in neural tube closure, leading to spina bifida in mutant embryos (Deng et al., 1997; Xu et al., 1999). Specific 
deletion of Fgfr1 in later CNS development has also shown its involvement in midbrain and hindbrain development (Trokovic et al., 2003).

New data about Fgfr3 and its role in CNS formation have recently been published. Among growth factors, FGF2 regulates oligodendrocyte development (Oh and Yong, 1996). Fgfr1 is expressed at all stages of oligodendrocyte development, Fgfr2 in differentiated oligodendrocytes and Fgfr3 in prooligodendrocytes, and is downregulated when cells enter terminal differentiation (Bansal et al., 1996; Bansal et al., 1996). In situ hybridization using oligodendrocyte markers has shown that Fgfr3-/- mice exhibit a delay in appearance of terminal differentiated oligodendrocytes, a phenomenon not linked to survival or proliferation defects. As a consequence, myelination is also delayed in those animals. Increased expression of GFAP, an astrocytic marker, in Fgfr3-/- has been reported (Oh et al., 2003; Pringle et al., 2003). Those data suggest that Fgfr3 is involved in regulation of differentiation of oligodendrocytes and astrocytes in the CNS (Oh et al., 2003; Pringle et al., 2003).

\section{Mammary gland development}

Several FGFs and FGFRs are involved in mammary gland development (Dickson et al., 2000). For example, FGF2 stimulates growth and inhibits differentiation of the normal mouse mammary gland epithelial cells (Lavandero et al., 1998). The highest mRNA levels of FGFR and their ligands are detected during involution in heifers (virgin bovine female) (Plath et al., 1998). FGFR1, FGFR2b and FGFR4 have also been detected in mammary cells (Bange et al., 2002; Jackson et al., 1997; Jackson et al., 1997; Marsh et al., 1999). 
Recently, use of an inducible drug-activated Fgfr1 in transgenic mice has revealed that this receptor is likely involved in positive regulation of lateral budding of the mammary ductal epithelium. The MAPK and Akt pathways are activated during this process. If treatment (and so subsequent activation of Fgfr1) is continuously performed, invasive lesions and hyperplasia are observed, suggesting that a prolonged activation of Fgfr1 could be involved in tumorigenesis (Welm et al., 2002). Moreover, Fgf8 expression levels have been linked to breast malignancy and the authors suggested that Fgfr1 and Fgfr4 may relay the signal (Marsh et al., 1999).

Utilization of dominant negative form of Fgfr2 in mice has shown that Fgfr2b positively regulates the mammary gland lobuloalveolar development during pregnancy. Those females cannot feed their pups even if a lactational response is observed (Jackson et al., 1997; Jackson et al., 1997). In wild-type mice, Fgfr2b is expressed only in the mammary gland epithelium, while its ligand, FGF7 originates in the stroma. Recently, a study showed that development of each mammary placode in mice involves different mechanisms. Compared to others, the fourth placode is not developmentally regulated by Fgfr2b mediated signals (Mailleux et al., 2002), suggesting a special feature for these glands.

Interestingly, the level of Fgfr2b and Fgf7 expression in the mammary gland is regulated by estradiol and progesterone; Fgf7 is upregulated by estradiol while progesterone has no effects. On the contrary in peripubertal and mature virgin mice, estradiol decreased the levels of the receptor while progesterone stimulated it. Thus, it appears that mammary gland development may be regulated by ovarian hormones through regulation of expression of Fgf7 / Fgfr2b signaling (Imagawa and Pedchenko, 2001). 


\section{Ear development}

FGFR1, FGFR2 and FGFR3 have been detected during inner ear development (Bermingham-McDonogh et al., 2001; Pickles and Chir, 2002; Pirvola et al., 2002). During mouse embryogenesis, Fgfr2b is heavily expressed in early developing structures before E10.5. During organogenesis after E10.5, Fgfr2 and Fgfr3 are predominantly expressed with an apparent bias towards the " $c$ " isoforms (Pickles, 2001). Nevertheless, Fgfr2b is still detected in nonsensory epithelium of the developing ear and is implicated in the development of walls of the cochlear spaces (Pickles and Chir, 2002; Pirvola et al., 2002). Targeted disruption of Fgfr2b leads notably to a severe dysgenesis of the cochleovestibular membranous labyrinth. Interestingly, the same study has suggested that Fgfr2b activation could depend on paracrine signals, a different model than the one proposed for limb development involving epithelial-mesenchymal interactions (Pirvola et al., 2000; Xu et al., 1998). Consistent with its pattern of expression, targeted disruption of Fgfr3 leads to inner ear defects. Indeed, it appears that Fgfr3 is involved in the differentiation of the pillar cells of the organ of Corti (Colvin et al., 1996; Pickles and Chir, 2002).

After birth, high levels of Fgfr3c, Fgfr1b and Fgfr2b have been detected in the neural/sensory region in some strains of mouse (Pickles, 2001; Pickles et al., 1998). On the contrary, the lateral walls of the cochlea express high levels of Fgfr1c (Pickles, 2001). Inactivation of Fgfr1 in the inner ear epithelium reduces dramatically the number of auditory hair cells, an event probably linked to a decreased number of progenitor cells (Pirvola et al., 2002). 


\section{Hepatic function}

FGFR4 is expressed in mature hepatocytes. Its disruption leads to defects of the liver function especially depleted gallbladders, an elevated bile acid pool and elevated excretion of bile acids ( $Y u$ et al., 2000). Indeed, the level of cholesterol 7alpha-hydroxylase, the limiting enzyme for bile acid synthesis, is elevated, a phenomenon that authors linked to upregulation of the Liver $X$ Receptor (LXR) function due to downregulation of its corepressor RIP140. The authors suggested that Fgfr4 controls RIP140 levels.

Moreover, cytotoxic studies have shown that Fgfr4-/- mice appeared to be very sensitive to $\mathrm{CCl} 4$, as reflected by increased liver mass, delayed hepatolobular repair and increased fibrosis. This phenomenon is linked to the downregulation of cytochrome P450 2E1 (CYP2E1) mRNA and protein, the enzyme responsible for normal liver detoxification of the CCl4 (Yu et al., 2002).

Some hypotheses about the regulation of these genes could be proposed. For example, activation of FGFR4, in addition to FGFR1 and FGFR3, can induce cellular transformation through stimulation of different Stat (1 \& 3) and PI3 kinase pathways (Hart et al., 2000). It is possible that these two pathways increased the expression of RIP140 and the CYP2E1.

\section{Roles of FGFRs in bone formation and human congenital diseases}

Important roles of FGF receptors in mammalian development and bone formation have been underscored by findings that missense mutations in FGFR13 resulted in more than 15 human disorders (McIntosh et al., 2000; Muenke and 
Wilkie, 2000). Most of them lead to skeletal dysplasias with craniosynostosis, limb abnormalities and short stature. Deafness, dermatological disorders and increase of cancer incidence are the other characterized symptoms. Table 2 is a collection of most mutations of the FGF receptors that are associated with skeletal dysplasias. Classification could be difficult because some mutations do not lead to the same symptoms depending on individuals.

\section{Craniosynostosis}

Craniosynostosis, premature fusion of one or several sutures of the skull, occurs with a frequency of approximately 1 in 2500 individuals (reviewed in (Katzen and McCarthy, 2000; Muenke and Wilkie, 2000; Renier et al., 2000)). So far, over sixty mutations, with a majority in FGFR2, have been found to be associated with nine clinically distinct craniosynostosis syndromes. These include Antley-Bixler-Like syndrome (ABS), Apert syndrome (AS), BeareStevenson syndrome (BSS), Crouzon syndrome (CS), Crouzon and Acanthosis Nigricans syndrome (CAN), Jackson-Weiss syndrome (JWS), Muenke syndrome (MS), and Pfeiffer syndrome (PS). The detailed characterization of these diseases can be found in a number of excellent reviews (Hehr and Muenke, 1999; Katzen and McCarthy, 2000; McIntosh et al., 2000; Muenke and Wilkie, 2000). All the mutations are dominant and all the syndromes exhibit craniofacial abnormalities with varying severity. The premature suture fusion may increase the intracranial pressure and, if no surgery is performed in early infancy, lead to further neurological impairments.

At the molecular level, a majority of mutations are localized in the Ig-like 
domains II and III, which bind to ligands (Plotnikov et al., 2000; Schlessinger et al., 2000). Many of these mutations caused loss or gain of a cysteine residue, leading to ligand independent activation of the receptors. Interestingly, some mutations display variable expressivity, in different individuals, which suggests involvement of genetic background factors in manifestation of the symptoms. Also, some mutations in other genes can reproduce an FGFR2 mutation phenotype; PAX6, JAGGED1, RIEG, FKHL7 mutations reproduce the FGFR2Ser351Cys missense mutation leading to a severe Crouzon/Pfeiffer syndrome associated with a Peters anomaly with ocular anterior chamber deficiency (Hehr and Muenke, 1999; Okajima et al., 1999). The common phenotypes suggest involvement of these genes downstream or upstream of the FGFR2 signaling pathway. Interestingly, mutation rates in some FGFR2 and FGFR3 associated craniosynostoses appear higher in male than female gametes and often increase with paternal age (Crow, 2000; Li et al., 2002). Recently, an investigation has suggested that mutations leading to FGFR2-S252W substitution are paradoxically enriched in human spermatogonial cells conferring a selective advantage to those cells (Goriely et al., 2003), providing a basis for the observed sex and age biases.

In order to create animal models for the FGF receptor-related inherited skeletal disorders, and to study the underlying mechanisms, a number of mutations, which correspond to human mutations, have been introduced into mice (Table 3). Zhou et al. (2000) introduced a P250R mutation (which corresponds to the P252R mutation found in Pfeiffer syndrome, PS) into the mouse Fgfr1 using gene targeting. The resulting animal exhibited craniosynostosis and skull malformations that mimic the conditions found in Pfeiffer patients characterized by premature fusion of coronal suture, and 
anterior-posteriorly shortened, laterally widened and vertically heightened neurocraniums (Figure 2A, B). Histologic analysis of early postnatal mutant mice revealed premature fusion of both sagittal and coronal sutures (Fig. 2C, D). The sutures of mutant mice had accelerated osteoblast proliferation and increased expression of genes related to osteoblast differentiation (Fig. 2E, F). Interestingly, their data also showed dramatically increased expression of $C b f a 1$ in the mutant sutures (Fig. 2E, F), suggesting that Cbfa1 may be a downstream target of Fgf/Fgfr1 signals (Zhou et al., 2000).

Using a similar strategy, Chen and Co-workers (2003) introduced, in the mouse genome, an Fgfr2-S250W mutation (which corresponds to human FGFR2S252W mutation that was found in AS syndrome, one of the most severe craniosynostosis syndromes). The resulting mice also showed some features that mimic the conditions found in AS patients (Chen et al., 2003). Unlike the PS model caused by Fgfr1-P250R mutation, the mutant mice carrying Fgfr2-S250W mutation only showed premature fusion of the coronal suture while the sagittal suture is normal (Fig. 3A). They also did not show apparent changes in proliferation or differentiation of osteoblast cells. Expression studies failed to detect obvious alterations of genes that are over expressed in PS mouse model, such as osteocalcin and Cbfa1. These observations may suggest that the PS and AP are caused by distinct mechanisms. Surprisingly, Chen et al. (2003) showed that the craniosynostosis is accompanied by decreased bone formation as measured by a calcein double-labeling assay (Fig. 3B, C), which is accompanied by increased apoptosis (Fig. 3D, F) and Bax expression (Fig. 3G, H) (Chen et al., 2003). This observation suggests that cell death triggered by the altered Fgfr2mediated signals is a primary reason for the defects. 
Suture development involves a coordinated process of mesenchymal cell condensation, proliferation, and differentiation to mature osteoblasts. Theoretically, increased osteoblast cell proliferation can increase overlapping areas of osteogenetic fronts and, therefore, result in premature closure. On the other hand, the increased differentiation can result in craniosynostosis due to accelerated bone formation. The abnormal increase in apoptosis may result in a decrease of the number of cells in the suture and hence in the distance between the overlapping bones, there by allowing physical contact and eventually leading to premature closure. However, it is less clear how Fgfr1-P250R and Fgfr2-S250W mutations result in craniosynostosis with distinctive features. It has been shown that expression of Fgfr1 is associated with increased osteogenic differentiation, and, consistently, activation of Fgfr1 dramatically enhances bone formation through up-regulation of a number of genes that promote osteoblast differentiation (Iseki et al., 1999; Zhou et al., 2000). On the other hand, Fgfr2 is only expressed in the periosteum of flat bones and at high levels in proliferating osteoprogenitor cells, where Fgfr1 transcripts are not detected (Chen et al., 2003; Iseki et al., 1999) Thus, the differential spatial expression of these two receptors plays an essential role in maintaining the cell proliferation-differentiation-cell death balance in the developing skull vault.

Because the FGFR2-S252W mutation caused loss of a cysteine residue in the highly conserved linker region between IgII and III, it was generally believed that the mutation would result in dimerization of the receptor through interaction of the unpaired cysteines, leading to ligand independent activation. However, it has been demonstrated that the FGFR2-S252W does not result in constitutive activation of the receptor, but instead, binds ligands tighter 
(Anderson et al., 1998). It was also demonstrated in another study that FGFR2S252W mutation altered the specificity of FGFR2 for its ligands (Yu et al., 2000). In this study, Yu et al. (2000) demonstrated that the FGFR2-S252W mutation allows the mesenchymal splice form, FGFR2c, to bind and be activated by the mesenchymally expressed ligands FGF7 and FGF10, and the epithelial splice form, FGFR2b, to be activated by the epithelial based FGF2, FGF6, and FGF9, allowing autocrine signaling in tissues that express these ligands (Yu et al., 2000). These data suggest that the severe phenotypes of AS likely result from ectopic ligand-dependent activation of FGFR2.

\section{Short-limbed dwarfisms}

Missense mutations in FGFR3 result in short-limbed dwarfisms, including achondroplasia $(\mathrm{ACH})$, thanatophoric dysplasia (TD), Severe Achondroplasia with Developmental Delay with Acanthosis Nigricans (SADDAN) and hypochondroplasia $(\mathrm{HCH})$ (Table 2). Unlike the craniosynostosis syndromes, these short-limbed dwarfisms are primarily caused by abnormalities of long bones, which are formed by endochondral ossification. $\mathrm{ACH}$ is the most common form of human dwarfism with a frequency of approximately 1 in 20,000 live births. ACH patients display a characteristic phenotype of rhizomelic dwarfism (most pronounced in the proximal portion of the limbs), relative macrocephaly, exaggerated lumbar lordosis and minimal proliferation of growth plate cartilage of long bones (Oberklaid et al., 1979; Rousseau et al., 1994; Shiang et al., 1994). $\mathrm{ACH}$ is most frequently (approximately 90\%, G380R \& G375C) (Rousseau et al., 1994; Shiang et al., 1994; Superti-Furga et al., 1995). 
TD is common, but associated with more severe neonatal lethal skeletal dysplasia (Orioli et al., 1986; Tavormina et al., 1995). Based on their clinic features, TD are sub-grouped into TD-I, which exhibit straight femurs and severe cloverleaf skull, and TD-II, which display curved femurs and mild or lacking cloverleaf skull changes in TD-I. All cases of TD-II are caused by a K650E mutation in the tyrosine kinase domain, whereas several different point mutations, including R248C, S249C, S371C, Stop807G, Stop807R, and Stop807C, have been shown to give rise to TD-I (Bonaventure et al., 1996; Rousseau et al., 1996; Rousseau et al., 1996; Rousseau et al., 1996; Rousseau et al., 1996; Rousseau et al., 1996; Rousseau et al., 1995). Most individuals with TD-I harbor the R248C mutation, with the other mutations occurring less frequently (Rousseau et al., 1996; Rousseau et al., 1996; Rousseau et al., 1996; Rousseau et al., 1996; Rousseau et al., 1996; Rousseau et al., 1995; Tavormina et al., 1995).

Interestingly, the amino acid K650 (which causes TDII when mutated into E650) could be mutated on two additional manners leading to two distinct diseases. When mutated to M650 (found in four unrelated individuals), it causes SADDAN (Bellus et al., 1999; Tavormina et al., 1999). The SADDAN patients exhibit skeletal dysplasia and survive the perinatal period. In addition, acanthosis nigricans and central nervous system structural anomalies and functional neurologic impairments, such as hearing loss, are observed in the surviving SADDAN patients. When the $\mathrm{K} 650$ is mutated to N650, it causes $\mathrm{HCH}$ (Rousseau et al., 1996), a short-limbed syndrome with similar, but milder skeletal dysplasia than $\mathrm{ACH}, \mathrm{TD}$ and SADDAN. HCH can also result from a number of mutations at other domains of FGFR3 (Table 2).

The similarities of skeletal dysplasia with graded severity in $\mathrm{HCH}, \mathrm{ACH}$, 
TD and SADDAN suggest a common basis underlying these diseases. Several lines of evidence indicate that the graded severity is of a quantitative nature rather than a qualitative one. First, patients heterozygous for both $\mathrm{ACH}$ and $\mathrm{HCH}$ alleles have a stronger phenotype than that seen with each allele alone (Hecht et al., 1987). Second, patients who are homozygous for the ACH alleles exhibit phenotypes similar to that of the TD patients (McKusick et al., 1973). Third, when K644E mutation (corresponds to K650E in human) was introduced into mouse Fgfr3 using a cDNA knock-in approach, it was expressed at $10 \%$ of the wild-type Fgfr3 level. The homozygous mice carrying this markedly attenuated TDII allele displayed features resembling $\mathrm{ACH}$, while the heterozygous mice displayed mild skeletal dysplasia, mimicking $\mathrm{HCH}$ condition (Li et al., 1999). However, when the same mutation was expressed at a level equivalent to the wild-type allele, it generated phenotypes mimicking TD (Iwata et al., 2000). Consistently, in vitro analyses indicate that FGFR3 cDNAs carrying mutations for $\mathrm{ACH}$ and TD exhibited a graded activation of their tyrosine kinase activities with wild type $<$ ACH $<$ TD (Chen et al., 1999; Iwata et al., 2001; Naski et al., 1996).

So far a dozen animal models carrying various mutations in Fgfr3 have been generated (Table 3). These mice, different extents, exhibit features mimicking the corresponding human conditions (reviewed in Brodie et al., 2003). Studies of these mice indicated that Fgfr3 signals play an essential role in inhibiting proliferation and differentiation of chondrocytes. Consequently, the ligand independent activation of Fgfr3 results in remarkably decreased chondrogenesis and bone growth, leading to dwarfism. Conversely, mutant mice carrying Fgfr3-null mutations exhibited increased proliferation of chondrocytes 
in the proliferation zone of growth plate, resulting in faster and prolonged endochondral bone growth (Colvin et al., 1996; Deng et al., 1996). This observation leads to the conclusion that FGFR3 is a negative regulator of bone growth. Further analyses revealed involvement of many downstream molecules in multiple signal transduction pathways, including Stats (Chen et al., 1999; Chen et al., 2001; Su et al., 1997), cell cycle inhibitors (Li et al., 1999; Su et al., 1997), PTHrP (Chen et al., 2001) (discussed further below).

Of note, most analyses of these mice were performed at perinatal and early postnatal stages, as many models did not exhibit obvious skeletal defects until after birth (Chen et al., 1999; Chen et al., 2001; Li et al., 1999). Nonetheless, the most extensive analyses were performed using the model for TDII mutation (Fgfr3-K644E), which die at birth (Iwata et al., 2000). Interestingly, the mutant embryos exhibited enhanced proliferation of growth plate chondrocytes during a limited time in early stages of endochondral ossification (embryonic day 14-15). However, at a later gestational age (E18), the mutant chondrocytes proliferate at a rate similar to controls. In contrast, decreased differentiation of chondrocytes continued to be observed throughout the period during which long bone development was studied. The significance of this observation is that the suppression of differentiation alone during embryonic stages of development could retard endochondral bone growth, while the effective inhibition of long bone growth at postnatal stages requires both impaired proliferation and differentiation. Alternatively, it argues that the cause of the shortened limbs in the TD model may be different from other models of activating Fgfr3, in which the phenotype becomes obvious in the postnatal stage (Chen et al., 1999; Chen et al., 2001; Li et al., 1999; Wang et al., 1999). 


\section{Cancer}

Mutations that activate FGF receptors, most frequently FGFR3, have also been found in many forms of cancers. Jang et al. (2001) reported two mutations in FGFR2, S267P in IgIIIa and a splice site mutation $(940-2 \mathrm{~A} \rightarrow \mathrm{G})$ in IgIIIc, in gastric cancer patients (Jang et al., 2001). Interestingly, these heterozygous somatic mutations are identical to the germinal activating mutations that are responsible for CS, AS and PS. Activating mutations of FGFR3 previously identified in lethal (Cappellen et al., 1999; Kimura et al., 2001) and non-lethal skeletal dysplasias were also found in bladder cancers (van Rhijn et al., 2002). Screening for FGFR3 mutations in human colorectal carcinomas, Jang et al. (2000) found novel mutant transcripts by aberrant splicing and activation of cryptic splice sequences with high frequency, i.e. $50 \%$ of 36 primary tumors and $60 \%$ of 10 colorectal cancer cell lines (Jang et al., 2001). More missense mutations of FGFR3 have also been found in cervical carcinomas (Cappellen et al., 1999), and in urothelial papilloma (van Rhijn et al., 2002; van Rhijn et al., 2002).

In addition, chromosome translocation leading to the activation of FGFR1 or FGFR3 has been reported in a number of cancers. Translocation of the immunoglobulin heavy chain locus at chromosome 14q32 close to the FGFR3 gene (50-120 kb centromeric) in myeloma is a common process (Chesi et al., 1997; Richelda et al., 1997). FGFR3 is expressed at high levels in these tumors. Some of these cancers also bear somatic mutations (Y373C, K650E and K650M), which are responsible for short-limbed skeletal dysplasias. Chromosome translocation involving FGFR1 was reported in a clinical syndrome, stem-cell 
myeloproliferative disorder (B-or T-cell lymphoblastic leukemia/lymphoma with myeloid hyperplasia and peripheral blood eosinophilia) (Pebusque et al., 2000). The predicted fusion proteins, FOP-FGFR1, ECP1-FGFR1, and FIM-FGFR1, are putatively oncogenic due to constitutive kinase activity triggered by dimerization mediated by the protein-protein interaction motifs of the FGFR1 (Pebusque et al., 2000). A study using cultured cell line Ba/F3 indicated that the FOP-FGFR1 induces cell survival mediated by mitogen-activated protein kinase and phosphatidylinositol 3-kinase / Akt/mTOR pathways (Guasch et al., 2001).

\section{Signaling through FGFR}

\section{Membrane events linked to activation of FGFRs}

FGF receptors normally exist as inactivate monomers and are activated by their ligands through a classical multi-step pathway (Ullrich and Schlessinger, 1990). Theoretically, two FGF molecules (and heparin) bind to the extracellular IgII and IgIII of the receptor, leading to its homodimerization (Schlessinger et al., 2000). Crystal structures of FGF2 and FGFR1 have revealed the importance of the Cys residues in formation of a stable complex. The IgII interacts with the ligand through hydrophobic interactions whereas the IgIII interacts through polar as well as hydrophobic interactions (Stauber et al., 2000). The dimerization brings together the intracellular domains of the receptor leading to trans autophosphorylation of several critical tyrosine residues ${ }^{3}$. This, in turn, allows

\footnotetext{
${ }^{3}$ There are also reports that FGF-FGFR complexes internalize and trigger other transduction pathways in the nucleus and perinuclear structures. This mechanism could deliver FGF to other intracellular targets (Maher, 1996; Peng et al., 2001; Reilly and Maher, 2001; Stachowiak et al., 1997; Wiedlocha et al., 1994; Wiedlocha et al., 1995) but none of them have been identified.
} 
binding of FRS2 (FGFR Stimulated 2 Grb2 binding protein) through SH2 (Src Homology 2) domains and sequential recruitment of Grb2 (growth factor receptor-bound protein 2), Sos (son of sevenless nucleotide exchange factor), SHP2 (Src Homology 2 Phosphatase 2) and Shc. Those membrane-closed complexes allow activation of Ras, Raf, PLC $\gamma 1$ and MEK/ERK signaling (Blaikie et al., 1994; Goldfarb, 1996; Kouhara et al., 1997; Mohammadi et al., 1991; Xu et al., 1998). Activation of different protein kinases or transcription factors, such as PLC $\gamma 1$, PI3K, STAT, Cbfa1, Sox9, Src and so on, has also been described (Liu et al., 1999; Ong et al., 2001; Xu and Goldfarb, 2001).

\section{The MAPK, PLC $\gamma 1$ and PI3K pathways}

Different systems have provided evidence of MAPK, PLC $\gamma 1$ and PI3K activation by FGF signaling:

In the mouse embryo, it was recently demonstrated that known or suspected regions of FGFR signaling overlap (but don't completely coincide) with the strongest domains of ERK activation. Furthermore, a brief incubation with an inhibitor of FGF receptor specifically decreased the phospho-ERK staining (Corson et al., 2003).

Several cell culture experiments have also provided evidence of activation of the PI3K and PLC $\gamma 1$ pathways; for example, stimulation by FGF2-FGFR1 of adrenal cortex capillary endothelial (ACE) cells activate the MAPK and PI3K pathways, respectively by ERK and Akt phosphorylation (Sulpice et al., 2002). Using smooth muscle cells (SMCs), Hayashi et al. showed that FGF2 stimulates p38 MAPK-ERK pathway that is involved in the dedifferentiation of these cells, 
although no activation of PI3K signaling is observed (Hayashi et al., 1999).

Kay et al. showed that FGF2 treatment induced corneal endothelial cells to undergo EMT, which is characterized by proliferation and change of cell shape. Using specific inhibitors, they were able to link the PI3K pathway to both events and the PLC $\gamma 1$ pathway only to cell mitosis activation (Kay et al., 1998). Like the PI3K action on Ras, the PLC $\gamma 1$ protein is also important for FGF1-FGFR1-ERK2 activation as shown by G2/S transition experiments in Xenopus oocytes expressing human FGFR1 (Browaeys-Poly et al., 2000; Browaeys-Poly et al., 2001). These studies provide additional evidence that distinct FGF-activated pathways can act together or independently.

Other studies have implicated the FGF activated MAPK and PI3K pathways in inhibition of apoptosis or survival. It was shown that all-trans retinoic acid treatment of P19 embryonic carcinoma cells resulted in activation of caspase 3, leading to apoptosis. The presence of FGF2 inhibited $90 \%$ of the caspase-3-like activity due to increased phosphorylation of Bad, an anti-apoptotic member of the Bcl-2 family. These events have been directly associated with PI3K activation as illustrated by using specific inhibitors (Miho et al., 1999). Recently, one study has shown that survival of dopaminergic neurons, whose degeneration has been linked to appearance of Parkinson's disease, is enhanced through stimulation of Fgfr1c and MAPK by FGF20 (Ohmachi et al., 2003).

FGF signaling and its downstream pathways has also been involved in differentiation processes. Chen et al (Chen et al., 2000) have shown that Fgfr2 through the PI3K/PKB/Akt pathway is required for ES cells differentiation. A dominant mutant form of Fgfr2 suppresses the expression of several extracellular 
matrix proteins (laminin a1, b1 and g1)(collagen IV a1 and a2). A hypothesis is that FGF signaling through Fgfr2/PI3K induces expression of basal membrane components, a process involved in epithelial differentiation (Chen et al., 2000; Li et al., 2001; Li et al., 2001).

Recently, a number of FGF-induced inhibitors of FGFR signaling, Sprouty, Sef and Pyst proteins, have been identified (negative feedback). Those proteins inhibit specifically the MAPK pathway. Briefly, Sef interacts with Fgfr1 inhibiting the phosphorylation associated with activation of the receptor. Sprouty2 is tyrosine-phosphorylated following FGFR or EGF stimulation, a phenomenon that increases its affinity for $\mathrm{c}-\mathrm{Cbl}$, a down regulator of receptor-tyrosine kinase pathway. Finally, Pyst1 expression is increased by FGF signaling (in chicken neural plate) and following a negative feedback loop, Pyst1 activity decreases the levels of phospho-MAPK (Eblaghie et al., 2003; Fong et al., 2003; Kovalenko et al., 2003).

\section{Cbfa1 (core-binding transcription factor alpha subunit type 1)}

It was shown recently that activation of FGFR2 by FGF2 or FGF4 stimulates expression and activation of Cbfa1 and this process is most likely mediated by MAPK and PKC signaling pathway (Bodo et al., 2002; Kim et al., 2003; Xiao et al., 2002). Cbfa1 is a transcription factor that controls differentiation of hypertrophic chondrocytes and osteoblasts. Mice missing Cbfa1 have no osteoblasts and show deficits of chondrocyte maturation (Ducy et al., 1997). Human patients heterozygous for mutations or deletions of CBFA1 develop cleidocranial dysplasia (Mundlos et al., 1997). 
The first in vivo evidence demonstrating that FGF/FGFR signaling acts upstream of Cbfa1 came from analysis of mutant mice carrying the Fgfr1-P250R mutation (Zhou et al., 2000). As mentioned earlier, Fgfr1-P250R mutant mice exhibited features mimicking CS patients including premature fusion of both coronal and sagittal sutures. Expression studies revealed that mutant osteoblasts expressed Cbfa1 at much higher levels than wild-type cells. This observation suggests that Cbfa1 may be a downstream target of Fgf/Fgfr1 signals. Consistently, transfection of C3H10T1/2 cells with wild type or mutant Fgfr1 cDNA, or treating these cells with Fgf2 or Fgf8 could induce Cbfa1 expression. Their data also demonstrated that the increased Cbfa1 subsequently activates its downstream transcription targets, including osteocalcin and bone sialoprotein (Zhou et al., 2000), ultimately leading to accelerated differentiation of osteoblasts. Conversely, the retarded ossification was correlated with decreased expression of Cbfa1in Fgfr2c-/- embryos (Eswarakumar et al., 2002). However, no obvious alterations in expression of Cbfa1, osteocalcin and bone sialoprotein was found in mutant mice carrying Fgfr2-S250W mutation (Chen et al., 2003), which corresponds to human AS, suggesting distinct mechanisms underlying these syndromes.

\section{STAT (Signal transdcution and activator of transcription) proteins}

Several lines of evidence indicate that the activating mutations of FGFR3 cause skeletal dysplasias, in part, through the activation of STAT proteins. It was first demonstrated that expression of FGFR3-K650E in cultured cells could 
activate STAT1, which in turn up-regulated p21, a cell cycle regulator. Consistent with this finding, growth plate chondrocytes of human TDII patients exhibited high levels of activated STAT1 and p21. It was therefore proposed that STAT1 might act as a mediator of growth retardation in bone development through regulation of cell-cycle inhibitors (Su et al., 1997). Activation of STAT proteins was also observed in most animal models for short-limb dwarfism (Chen et al., 1999; Chen et al., 2001; Li et al., 1999). Importantly, studies using transgenic mice over expressing FGF indicated that the absence of STAT1 could override the inhibition of FGF signals on chondrocyte proliferation in cultured bones (Sahni et al., 1999) and in adult animals (Sahni et al., 2001).

Interestingly, analyses of animal models also revealed that an activating mutation of Fgfr3 results in the activation of multiple Stats, including Stat1, Stat5a and 5b (Chen et al., 1999; Chen et al., 2001; Li et al., 1999), suggesting a broader effect of FGF signals on the STAT proteins. Phosphorylation of multiple STAT proteins was also caused by expression of other receptors or treatment with FGFs (Hart et al., 2001; Hart et al., 2000; Smedley et al., 1999) possibly through a mechanism involving platelet-activating factor, JAK-2, and Src (Deo et al., 2002). Studies on animal models also revealed increased expression of several cell cycle inhibitors, including p21 and three other cell cycle inhibitors p16, p18 and p19 that belong to the Ink4 family (Li et al., 1999). This observation suggests that the activated STAT signaling must generate pleiotropic effects that may be mediated by multiple cell-cycle inhibitors and other unidentified factors. Consistent with this notion, introduction of a p21-null background into the mutant mice did not have any apparent influence on skeletal phenotypes, presumably due to functional redundancy of other cell cycle inhibitors (Li et al., 
1999).

\section{Interaction between FGF/FGFR and IHH/PTHrP signaling}

\section{pathways}

IHH (Indian hedgehog)/PTHrP (parathyroid hormone-related protein peptide, also PTHIP) signals represent an important pathway for bone growth. IHH and PTHrP function in a negative feedback loop to control the proliferation and differentiation of growth plate chondrocytes (Vortkamp et al., 1996). Based on this model, IHH, which is expressed in the maturing zone of chondrocytes, induces the expression of PTHrP in the periarticular perichondrium. The activation of PTHrP-R in prehypertrophic chondrocytes prevents them from differentiating into hypertrophic cells (Vortkamp et al., 1996).

Examination of mouse models carrying activated Fgfr3 revealed markedly decreased expression of IHH and the PTHrP receptor (Chen et al., 2001). In cultured bone rudiments treated with FGF2, it was demonstrated that the down regulation of $\mathrm{IHH}$ and PTHrP receptor occurred prior to the appearance of bone abnormality (Chen et al., 2001). These observations indicate that FGFR3 functions upstream of IHH and PTHrP receptor, and negatively regulates their expression. Given a positive role of IHH signals in chondrocyte proliferation (St-Jacques et al., 1999), it is conceivable that down regulation of $\mathrm{IHH}$ contributes to pathogenesis of FGFR3-associated skeletal dysplasias. Of note, mice deficient in IHH, PTHrP, or PTHrP-R exhibited premature chondrocyte hypertrophy, characterized by the expansion of the zone of hypertrophic chondrocytes (Lanske et al., 1996; St-Jacques et al., 1999; Vortkamp et al., 1996). However, the mice 
carrying activated Fgfr3, despite the downregulation of $\mathrm{IHH}$ and PTHrP-R expression, did not shown any signs of premature hypertrophy of chondrocytes, instead, they exhibited markedly reduced sizes of hypertrophic chondrocytes and much narrower zone of hypertrophic chondrocytes compared with those of control animals (Chen et al., 2001; Li et al., 1999; Naski et al., 1998). These data suggest that FGF/FGFR3 signaling inhibits chondrocyte differentiation independently, irrespective of IHH/ PTHrP signaling.

To further study the interaction between FGF/FGFR3 and IHH/PTHrP signaling during bone growth, Chen et al. (2001) tested whether the inhibition of chondrocyte differentiation by PTHrP-PTHrP-R signaling is dependent on FGF/FGFR3 signaling. Their data revealed that PTHrP treatment could inhibit chondrocyte differentiation in all cultured bones irrespective of their genotypes, i.e. whether they were wild type, Fgfr3-knockout or Fgfr3-activating mutations. Altogether, these observations indicate that FGF/FGFR3 and IHH/PTHrP signals inhibit chondrocyte differentiation in a dominant and independent manner (Chen et al., 2001).

Studying cultured bones isolated from a transgenic mice carrying FGFR3G380R, a recent study proposed a similar, yet distinct model of interactions among FGF/FGFR, IHH/PTHrP and BMP (Minina et al., 2002). While this model supports a negative role of FGF signaling in chondrocyte proliferation, it suggests that FGF/FGFR signaling accelerates, rather than inhibits, hypertrophic differentiation independent of the IHH/PTHrP system. They believed that the reduced domain of hypertropic zone is secondary to the rapid differentiation and slower proliferation of chondrocytes. Although this explanation may fit their data obtained from cultured bones, it may not reconcile with the facts that Fgfr3 - 
/- mice exhibit accelerated chondrocyte differentiation in the growth plates characterized by both expanded zone of hypertropic chondrocytes and enlarged sizes of hypertropic chondrocytes (Deng et al., 1996). This last model also fails to explain why the fast differentiation should result in markedly reduced sizes of hypertrophic chondrocytes in mice carrying knock-in mutations that activate Fgfr3 (Chen et al., 1999; Chen et al., 2001; Li et al., 1999; Wang et al., 1999).

Their data also revealed that FGF and BMP signaling act antagonistically during chondrogenesis. Consistently, treatment of cultured bones isolated from FGFR3-G380R mice with BMP could rescue the decreased rate of chondrocyte proliferation and the reduced size of the hypertrophic zone (Minina et al., 2002). This observation provides a potential approach for therapeutic treatment of these skeletal dysplasias.

\section{Conclusions and future directions}

Since the initial identification and cloning of FGF receptors 15 years ago (Lee et al., 1989; Olwin et al., 1986), significant progress has been achieved toward the understanding of physiological roles of these receptors. Mounting evidence revealed that FGF/FGFR signals play many fundamental roles at multiple levels. At a molecular level, as summarized in the figure 4, they interact with numerous signal transduction pathways and regulate expression of many downstream targets. Through this signaling network, FGFs/FGFRs specify many cellular events, such as proliferation, differentiation, adhesion, movement, survival and transformation. During embryonic development, FGF/FGFR signals play a major role in mesoderm organization and patterning, body axis 
and neural axis formation, and tissue/organ induction. Throughout postnatal development, FGF/FGFR signals are required for maintaining normal functions of many organs and tissues. In this respect, activating mutations of FGFR1-3 that result in many human skeletal dysplasias is the most significant finding, which uncovers indispensable roles of FGFs in both endochondral and intramembranous ossification.

Despite this substantial progress, many questions still remain. Different mutations in a receptor result in activation of the receptor at varying levels; however, it is not clear how these events yield different syndromes. For instance, FGFR3-250 and FGFR3-380 result in craniosynostosis (affecting intramembranous ossification) and achondroplasia (affecting endochondral bone formation), respectively. It is also not clear different mutations of the same amino acid, i.e. FGFR3-K650E, FGFR3-K650N and FGFR3-K650M, could be responsible for syndromes with distinct phenotypes, TDII, HCH and SADDAN, respectively. Presumably, these different mutations have activated different signaling transduction pathways and caused different consequences to the patients. If this is the case, what is the sensor (or sensors) for these varying activating FGFR signals? What is the switch (or switches) to determine which pathways should be turned on or shut off or additive? Finally, future studies will also be directed to uncover the pathways and downstream mediators that respond to each of these mutations that cause distinct phenotypes.

A dozen mouse models for human skeletal dysplasias have been generated. While these models will facilitate efforts to determine interacting pathways and downstream mediators; importantly, they may also be used for therapeutic studies. Because these diseases are dominant, heterozygous mice are 
ideal for screening therapeutic drugs and/or physiological repressors that inhibit FGF receptor activity to reverse the phenotypes. The newly developed RNAi technique may also be used to specifically inhibit the expression of mutant forms of receptors, but not the wild type forms, given its high specificity (Borkhardt, 2002; Brummelkamp et al., 2002).

Last, but not least, the absence of Fgfr1 and Fgfr2 result in early embryonic lethality. Their roles in many cell lineages in late embryonic and postnatal development remain to be determined. The existing conditional mutant mice should facilitate this research by using spatial and temporal-regulated CreLoxP approaches (De Moerlooze et al., 2000; Xu et al., 2002; Yu et al., 2003) 


\section{Legends of the figures}

Figure 1. Structure of FGFR with the different Ig-like extracellular (and the possible splicing isoforms, IIIb and IIIc), transmembrane (TM) and the two intracellular tyrosine kinase (TK) domains.

Figure 2. Fgfr1-P250R mutation in mice results in craniosynostosis that mimics human Pfeiffer syndrome. A. Head morphology of p16 wild-type (WT) and Fgfr1 $^{\mathrm{P} 250 \mathrm{R} /+}(250 /+)$ mice. The arrow in (a) points to dome-shaped head of mutant

mice. B. Skull morphology of P16 WT, 250/+ mice. Lines mark length of anterior frontal (Af) and posterior frontal sutures (Pf). Co: coronal suture, La: lambdoid suture, Op: occipito-interparietal suture, Sa: sagittal suture. Notice premature fusion of the Af, Pf, Sa and Co sutures in 250/+ mice. C and D. H\&E staining revealed premature fusion of sagittal suture from P20 mutant (arrows in D) compared with wild type control (arrows in C). E and F. In situ hybridization using an antisense probe for Cbfa1 in wild-type (E) and 250/+ (F) sutures. Bar: $230 \mu \mathrm{m}$ for C-F.

Figure 3. The Fgfr2-S250W mutation results in phenotypes mimicking human Apert syndrome. (A) Top view of P20 wild type (Wt) and Fgfr2 $2^{5250 \mathrm{~W} /+}(\mathrm{Mt})$ mice, notice the mutant have significantly shortened head, and premature fused coronal suture (arrows). A-P: anterior-posterior and L-R: left-right axes. Sa: sagittal; Co, coronal; and La, lambdoid sutures. (B and C) Monitoring of bone formation using calcein double labeling. The mutant has less bone formed during a 14 day labeling period in comparison with wild type (compare distance 
between two layers of bone pointed by arrows). (D and E) TUNEL assay reveals increased apoptosis in mutant coronal sutures in comparison with controls. $(\mathrm{F}$, G) Mutant sutures also exhibited significantly increased Bax signals than controls as revealed by immunohistochemistry.

Figure 4. A summary of FGFR signaling and regulatory network discussed in this article. 


\section{References}

Anderson J, Burns HD, Enriquez-Harris P, Wilkie AO, Heath JK 1998. Apert syndrome mutations in fibroblast growth factor receptor 2 exhibit increased affinity for FGF ligand. Hum Mol Genet 7:1475-83.

Bange J, Prechtl D, Cheburkin Y, Specht K, Harbeck N, Schmitt M, Knyazeva T, Muller S, Gartner S, Sures I, Wang H, Imyanitov E, Haring HU, Knayzev P, Iacobelli S, Hofler H, Ullrich A 2002. Cancer progression and tumor cell motility are associated with the FGFR4 $\operatorname{Arg}(388)$ allele. Cancer Res 62:840-7.

Bansal R, Kumar M, Murray K, Morrison RS, Pfeiffer SE 1996. Regulation of FGF receptors in the oligodendrocyte lineage. Mol Cell Neurosci 7:263-75.

Bansal R, Kumar M, Murray K, Pfeiffer SE 1996. Developmental and FGF-2mediated regulation of syndecans (1-4) and glypican in oligodendrocytes. Mol Cell Neurosci 7:276-88.

Bellus GA, Bamshad MJ, Przylepa KA, Dorst J, Lee RR, Hurko O, Jabs EW, Curry CJ, Wilcox WR, Lachman RS, Rimoin DL, Francomano CA 1999.

A novel skeletal dysplasia with developmental delay and acanthosis nigricans is caused by a Lys650Met mutation in the fibroblast growth factor receptor 3 gene. Am J Med Genet 85:53-65.

Bermingham-McDonogh O, Stone JS, Reh TA, Rubel EW 2001. FGFR3 expression during development and regeneration of the chick inner ear sensory epithelia. Dev Biol 238:247-59.

Blaikie P, Immanuel D, Wu J, Li N, Yajnik V, Margolis B 1994. A region in Shc distinct from the $\mathrm{SH} 2$ domain can bind tyrosine-phosphorylated growth factor receptors. J Biol Chem 269:32031-4.

Bodo M, Lilli C, Bellucci C, Carinci P, Calvitti M, Pezzetti F, Stabellini G, Bellocchio S, Balducci C, Carinci F, Baroni T 2002. Basic fibroblast growth factor autocrine loop controls human osteosarcoma phenotyping and differentiation. Mol Med 8:393-404.

Bonaventure J, Rousseau F, Legeai-Mallet L, Le Merrer M, Munnich A, Maroteaux P 1996. Common mutations in the gene encoding fibroblast growth factor receptor 3 account for achondroplasia, hypochondroplasia and thanatophoric dysplasia. Acta Paediatr Suppl 417:33-8.

Borkhardt A 2002. Blocking oncogenes in malignant cells by RNA interference-new hope for a highly specific cancer treatment? Cancer Cell 2:167-8.

Brodie SG, Deng CX 2003. Mouse models orthologous to FGFR3-related skeletal dysplasias. Pediatr Pathol Mol Med 22:87-103.

Browaeys-Poly E, Cailliau K, Vilain JP 2000. Signal transduction pathways 
triggered by fibroblast growth factor receptor 1 expressed in Xenopus laevis oocytes after fibroblast growth factor 1 addition. Role of Grb2, phosphatidylinositol 3-kinase, Src tyrosine kinase, and phospholipase Cgamma. Eur J Biochem 267:6256-63.

Browaeys-Poly E, Cailliau K, Vilain JP 2001. Transduction cascades initiated by fibroblast growth factor 1 on Xenopus oocytes expressing MDA-MB-231 mRNAs. Role of Grb2, phosphatidylinositol 3-kinase, Src tyrosine kinase, and phospholipase Cgamma. Cell Signal 13:363-8.

Brummelkamp TR, Bernards R, Agami R 2002. Stable suppression of tumorigenicity by virus-mediated RNA interference. Cancer Cell 2:243-7.

Capdevila J, Izpisua Belmonte JC 2001. Patterning mechanisms controlling vertebrate limb development. Annu Rev Cell Dev Biol 17:87-132.

Cappellen D, De Oliveira C, Ricol D, de Medina S, Bourdin J, Sastre-Garau X, Chopin D, Thiery JP, Radvanyi F 1999. Frequent activating mutations of FGFR3 in human bladder and cervix carcinomas. Nat Genet 23:18-20.

Chen L, Adar R, Yang X, Monsonego EO, Li C, Hauschka PV, Yayon A, Deng CX 1999. Gly369Cys mutation in mouse FGFR3 causes achondroplasia by affecting both chondrogenesis and osteogenesis. J Clin Invest 104:1517-25.

Chen L, Li C, Qiao W, Xu X, Deng C 2001. A Ser(365)--\&gt;Cys mutation of fibroblast growth factor receptor 3 in mouse downregulates Ihh/PTHrP signals and causes severe achondroplasia. Hum Mol Genet 10:457-65.

Chen L, Li D, Li C, Engel A, Deng C 2003. A Ser250Trp substitution in mouse fibroblast growth factor receptor 2 (Fgfr2) results in craniosynostosis. Bone:In press.

Chen Y, Li X, Eswarakumar VP, Seger R, Lonai P 2000. Fibroblast growth factor (FGF) signaling through PI 3-kinase and Akt/PKB is required for embryoid body differentiation. Oncogene 19:3750-6.

Chesi M, Nardini E, Brents LA, Schrock E, Ried T, Kuehl WM, Bergsagel PL 1997. Frequent translocation $\mathrm{t}(4 ; 14)(\mathrm{p} 16.3 ; \mathrm{q} 32.3)$ in multiple myeloma is associated with increased expression and activating mutations of fibroblast growth factor receptor 3. Nat Genet 16:260-4.

Ciruna B, Rossant J 2001. FGF signaling regulates mesoderm cell fate specification and morphogenetic movement at the primitive streak. Dev Cell 1:37-49.

Ciruna BG, Schwartz L, Harpal K, Yamaguchi TP, Rossant J 1997. Chimeric analysis of fibroblast growth factor receptor-1 (Fgfr1) function: a role for FGFR1 in morphogenetic movement through the primitive streak. Development 124:2829-41. 
Clement-Lacroix P, Friteau L, Damais C 1991. Activation of human dermal fibroblasts by fibroblast growth factors (FGFs) and/or interleukin-1 beta (IL-1 beta). Lymphokine Cytokine Res 10:111-4.

Coffin JD, Florkiewicz RZ, Neumann J, Mort-Hopkins T, Dorn GWn, Lightfoot P, German R, Howles PN, Kier A, O'Toole BA, et al. 1995. Abnormal bone growth and selective translational regulation in basic fibroblast growth factor (FGF-2) transgenic mice. Mol Biol Cell 6:1861-73.

Colvin JS, Bohne BA, Harding GW, McEwen DG, Ornitz DM 1996. Skeletal overgrowth and deafness in mice lacking fibroblast growth factor receptor 3. Nat Genet 12:390-7.

Corson LB, Yamanaka Y, Lai KM, Rossant J 2003. Spatial and temporal patterns of ERK signaling during mouse embryogenesis. Development 130:4527-37.

Coulier F, Pontarotti P, Roubin R, Hartung H, Goldfarb M, Birnbaum D 1997. Of worms and men: an evolutionary perspective on the fibroblast growth factor (FGF) and FGF receptor families. J Mol Evol 44:43-56.

Crow JF 2000. The origins, patterns and implications of human spontaneous mutation. Nat Rev Genet 1:40-7.

Curran KL, Grainger RM 2000. Expression of activated MAP kinase in Xenopus laevis embryos: evaluating the roles of FGF and other signaling pathways in early induction and patterning. Dev Biol 228:41-56.

De Moerlooze L, Spencer-Dene B, Revest J, Hajihosseini M, Rosewell I, Dickson C 2000. An important role for the IIIb isoform of fibroblast growth factor receptor 2 (FGFR2) in mesenchymal-epithelial signalling during mouse organogenesis. Development 127:483-92.

Deng C, Bedford M, Li C, Xu X, Yang X, Dunmore J, Leder P 1997. Fibroblast growth factor receptor-1 (FGFR-1) is essential for normal neural tube and limb development. Dev Biol 185:42-54.

Deng C, Wynshaw-Boris A, Zhou F, Kuo A, Leder P 1996. Fibroblast growth factor receptor 3 is a negative regulator of bone growth. Cell 84:911-21.

Deng CX, Wynshaw-Boris A, Shen MM, Daugherty C, Ornitz DM, Leder P 1994. Murine FGFR-1 is required for early postimplantation growth and axial organization. Genes Dev 8:3045-57.

Deo DD, Axelrad TW, Robert EG, Marcheselli V, Bazan NG, Hunt JD 2002. Phosphorylation of STAT-3 in response to basic fibroblast growth factor occurs through a mechanism involving platelet-activating factor, JAK-2, and Src in human umbilical vein endothelial cells. Evidence for a dual kinase mechanism. J Biol Chem 277:21237-45. 
Dickson C, Creer A, Fantl V 2000. Mammary gland oncogenes as indicators of pathways important in mammary gland development. Oncogene 19:1097-101.

Ducy P, Zhang R, Geoffroy V, Ridall AL, Karsenty G 1997. Osf2/Cbfa1: a transcriptional activator of osteoblast differentiation. Cell 89:747-54.

Eblaghie MC, Lunn JS, Dickinson RJ, Munsterberg AE, Sanz-Ezquerro JJ, Farrell ER, Mathers J, Keyse SM, Storey K, Tickle C 2003. Negative feedback regulation of FGF signaling levels by Pyst1/MKP3 in chick embryos. Curr Biol 13:1009-18.

Eriksson AE, Cousens LS, Weaver LH, Matthews BW 1991. Three-dimensional structure of human basic fibroblast growth factor. Proc Natl Acad Sci U S A 88:3441-5.

Eswarakumar VP, Monsonego-Ornan E, Pines M, Antonopoulou I, Morriss-Kay GM, Lonai P 2002. The IIIc alternative of Fgfr2 is a positive regulator of bone formation. Development 129:3783-93.

Fong CW, Leong HF, Wong ES, Lim J, Yusoff P, Guy GR 2003. Tyrosine phosphorylation of Sprouty2 enhances its interaction with c-Cbl and is crucial for its function. J Biol Chem 278:33456-64.

Ford-Perriss M, Abud H, Murphy M 2001. Fibroblast growth factors in the developing central nervous system. Clin Exp Pharmacol Physiol 28:493-503.

Goldfarb M 1996. Functions of fibroblast growth factors in vertebrate development. Cytokine Growth Factor Rev 7:311-325.

Goriely A, McVean GA, Rojmyr M, Ingemarsson B, Wilkie AO 2003. Evidence for selective advantage of pathogenic FGFR2 mutations in the male germ line. Science 301:643-6.

Gospodarowicz D 1974. Localisation of a fibroblast growth factor and its effect alone and with hydrocortisone on 3T3 cell growth. Nature 249:123-7.

Guasch G, Ollendorff V, Borg JP, Birnbaum D, Pebusque MJ 2001. 8p12 stem cell myeloproliferative disorder: the FOP-fibroblast growth factor receptor 1 fusion protein of the $t(6 ; 8)$ translocation induces cell survival mediated by mitogenactivated protein kinase and phosphatidylinositol 3-kinase/Akt/mTOR pathways. Mol Cell Biol 21:8129-42.

Hart KC, Robertson SC, Donoghue DJ 2001. Identification of tyrosine residues in constitutively activated fibroblast growth factor receptor 3 involved in mitogenesis, Stat activation, and phosphatidylinositol 3-kinase activation. Mol Biol Cell 12:931-42.

Hart KC, Robertson SC, Kanemitsu MY, Meyer AN, Tynan JA, Donoghue DJ 2000. Transformation and Stat activation by derivatives of FGFR1, FGFR3, and 
FGFR4. Oncogene 19:3309-20.

Hayashi K, Takahashi M, Kimura K, Nishida W, Saga H, Sobue K 1999. Changes in the balance of phosphoinositide 3-kinase/protein kinase B (Akt) and the mitogen-activated protein kinases (ERK/p38MAPK) determine a phenotype of visceral and vascular smooth muscle cells. J Cell Biol 145:727-40.

Hecht JT, Francomano CA, Horton WA, Annegers JF 1987. Mortality in achondroplasia. Am J Hum Genet 41:454-64.

Hehr U, Muenke M 1999. Craniosynostosis syndromes: from genes to premature fusion of skull bones. Mol Genet Metab 68:139-51.

Imagawa W, Pedchenko VK 2001. In vivo inhibition of keratinocyte growth factor receptor expression by estrogen and antagonism by progesterone in the mouse mammary gland. J Endocrinol 171:319-27.

Iseki S, Wilkie AO, Morriss-Kay GM 1999. Fgfr1 and Fgfr2 have distinct differentiation- and proliferation-related roles in the developing mouse skull vault. Development 126:5611-20.

Iwata T, Chen L, Li C, Ovchinnikov DA, Behringer RR, Francomano CA, Deng CX 2000. A neonatal lethal mutation in FGFR3 uncouples proliferation and differentiation of growth plate chondrocytes in embryos. Hum Mol Genet 9:160313.

Iwata T, Li CL, Deng CX, Francomano CA 2001. Highly activated Fgfr3 with the K644M mutation causes prolonged survival in severe dwarf mice. Hum Mol Genet 10:1255-64.

Jackson D, Bresnick J, Dickson C 1997. A role for fibroblast growth factor signaling in the lobuloalveolar development of the mammary gland. J Mammary Gland Biol Neoplasia 2:385-92.

Jackson D, Bresnick J, Rosewell I, Crafton T, Poulsom R, Stamp G, Dickson C 1997. Fibroblast growth factor receptor signalling has a role in lobuloalveolar development of the mammary gland. J Cell Sci 110:1261-8.

Jang JH, Shin KH, Park JG 2001. Mutations in fibroblast growth factor receptor 2 and fibroblast growth factor receptor 3 genes associated with human gastric and colorectal cancers. Cancer Res 61:3541-3.

Katzen JT, McCarthy JG 2000. Syndromes involving craniosynostosis and midface hypoplasia. Otolaryngol Clin North Am 33:1257-84, vi.

Kay EP, Park SY, Ko MK, Lee SC 1998. Fibroblast growth factor 2 uses PLCgamma1 for cell proliferation and PI3-kinase for alteration of cell shape and cell proliferation in corneal endothelial cells. Mol Vis 4:22. 
Kim HJ, Kim JH, Bae SC, Choi JY, Ryoo HM 2003. The protein kinase C pathway plays a central role in the fibroblast growth factor-stimulated expression and transactivation activity of Runx2. J Biol Chem 278:319-26.

Kim I, Moon S, Yu K, Kim U, Koh GY 2001. A novel fibroblast growth factor receptor-5 preferentially expressed in the pancreas(1). Biochim Biophys Acta 1518:152-6.

Kimura T, Suzuki H, Ohashi T, Asano K, Kiyota H, Eto Y 2001. The incidence of thanatophoric dysplasia mutations in FGFR3 gene is higher in low-grade or superficial bladder carcinomas. Cancer 92:2555-61.

Kouhara H, Hadari YR, Spivak-Kroizman T, Schilling J, Bar-Sagi D, Lax I, Schlessinger J 1997. A lipid-anchored Grb2-binding protein that links FGFreceptor activation to the Ras/MAPK signaling pathway. Cell 89:693-702.

Kovalenko D, Yang X, Nadeau RJ, Harkins LK, Friesel R 2003. Sef inhibits fibroblast growth factor signaling by inhibiting FGFR1 tyrosine phosphorylation and subsequent ERK activation. J Biol Chem 278:14087-91.

Lanske B, Karaplis AC, Lee K, Luz A, Vortkamp A, Pirro A, Karperien M, Defize LHK, Ho C, Mulligan RC, Abou-Samra AB, Juppner H, Segre GV, Kronenberg HM 1996. PTH/PTHrP receptor in early development and Indian hedgehogregulated bone growth. Science 273:663-6.

Launay C, Fromentoux V, Shi DL, Boucaut JC 1996. A truncated FGF receptor blocks neural induction by endogenous Xenopus inducers. Development 122:869-80.

Lavandero S, Chappuzeau A, Sapag-Hagar M, Oka T 1998. In vivo and in vitro evidence of basic fibroblast growth factor action in mouse mammary gland development. FEBS Lett 439:351-6.

Lee PL, Johnson DE, Cousens LS, Fried VA, Williams LT 1989. Purification and complementary DNA cloning of a receptor for basic fibroblast growth factor. Science 245:57-60.

Li C, Chen L, Iwata T, Kitagawa M, Fu XY, Deng CX 1999. A Lys644Glu substitution in fibroblast growth factor receptor 3 (FGFR3) causes dwarfism in mice by activation of STATs and ink 4 cell cycle inhibitors. Hum Mol Genet 8:3544 .

Li C, Guo H, Xu X, Weinberg W, Deng CX 2001. Fibroblast growth factor receptor 2 (Fgfr2) plays an important role in eyelid and skin formation and patterning. Dev Dyn 222:471-83.

Li WH, Yi S, Makova K 2002. Male-driven evolution. Curr Opin Genet Dev 12:650-6. 
Li X, Chen Y, Scheele S, Arman E, Haffner-Krausz R, Ekblom P, Lonai P 2001. Fibroblast growth factor signaling and basement membrane assembly are connected during epithelial morphogenesis of the embryoid body. J Cell Biol 153:811-22.

Liu J, Huang C, Zhan X 1999. Src is required for cell migration and shape changes induced by fibroblast growth factor 1 . Oncogene 18:6700-6.

Maher PA 1996. Nuclear Translocation of fibroblast growth factor (FGF) receptors in response to FGF-2. J Cell Biol 134:529-36.

Mailleux AA, Spencer-Dene B, Dillon C, Ndiaye D, Savona-Baron C, Itoh N, Kato S, Dickson C, Thiery JP, Bellusci S 2002. Role of FGF10/FGFR2b signaling during mammary gland development in the mouse embryo. Development 129:53-60.

Marsh SK, Bansal GS, Zammit C, Barnard R, Coope R, Roberts-Clarke D, Gomm JJ, Coombes RC, Johnston CL 1999. Increased expression of fibroblast growth factor 8 in human breast cancer. Oncogene 18:1053-60.

Martin GR 1998. The roles of FGFs in the early development of vertebrate limbs. Genes Dev 12:1571-86.

Maruoka Y, Ohbayashi N, Hoshikawa M, Itoh N, Hogan BL, Furuta Y 1998. Comparison of the expression of three highly related genes, Fgf8, Fgf17 and Fgf18, in the mouse embryo. Mech Dev 74:175-7.

Mason I, Chambers D, Shamim H, Walshe J, Irving C 2000. Regulation and function of FGF8 in patterning of midbrain and anterior hindbrain. Biochem Cell Biol 78:577-84.

McIntosh I, Bellus GA, Jab EW 2000. The pleiotropic effects of fibroblast growth factor receptors in mammalian development. Cell Struct Funct 25:85-96.

McKusick VA, Kelly TE, Dorst JP 1973. Observations suggesting allelism of the achondroplasia and hypochondroplasia genes. J Med Genet 10:11-6.

Miho Y, Kouroku Y, Fujita E, Mukasa T, Urase K, Kasahara T, Isoai A, Momoi MY, Momoi T 1999. bFGF inhibits the activation of caspase-3 and apoptosis of P19 embryonal carcinoma cells during neuronal differentiation. Cell Death Differ 6:463-70.

Minina E, Kreschel C, Naski MC, Ornitz DM, Vortkamp A 2002. Interaction of FGF, Ihh/Pthlh, and BMP signaling integrates chondrocyte proliferation and hypertrophic differentiation. Dev Cell 3:439-49.

Mohammadi M, Honegger AM, Rotin D, Fischer R, Bellot F, Li W, Dionne CA, Jaye M, Rubinstein M, Schlessinger J 1991. A tyrosine-phosphorylated carboxyterminal peptide of the fibroblast growth factor receptor $(\mathrm{Flg})$ is a binding site for the SH2 domain of phospholipase C-gamma 1. Mol Cell Biol 11:5068-78. 
Muenke M, Wilkie A 2000. Craniosynostosis syndromes. In Scriver, C.R., Beaudet, A.L., Sly, W.S., Valle, D., Childs, B. and Vogelstein, B. (eds), The Metabolic and Molecular Bases of Inherited Disease, 8th edn. McGraw-Hill, New York, NY.

Mundlos S, Otto F, Mundlos C, Mulliken JB, Aylsworth AS, Albright S, Lindhout D, Cole WG, Henn W, Knoll JH, Owen MJ, Mertelsmann R, Zabel BU, Olsen BR 1997. Mutations involving the transcription factor CBFA1 cause cleidocranial dysplasia. Cell 89:773-9.

Naski MC, Colvin JS, Coffin JD, Ornitz DM 1998. Repression of hedgehog signaling and BMP4 expression in growth plate cartilage by fibroblast growth factor receptor 3. Development 125:4977-88.

Naski MC, Wang Q, Xu J, Ornitz DM 1996. Graded activation of fibroblast growth factor receptor 3 by mutations causing achondroplasia and thanatophoric dysplasia. Nat Genet 13:233-7.

Niswander L 2002. Interplay between the molecular signals that control vertebrate limb development. Int J Dev Biol 46:877-81.

Niswander L, Martin GR 1992. Fgf-4 expression during gastrulation, myogenesis, limb and tooth development in the mouse. Development 114:755-68.

Oberklaid F, Danks DM, Jensen F, Stace L, Rosshandler S 1979. Achondroplasia and hypochondroplasia. Comments on frequency, mutation rate, and radiological features in skull and spine. J Med Genet 16:140-6.

Oh LY, Denninger A, Colvin JS, Vyas A, Tole S, Ornitz DM, Bansal R 2003. Fibroblast growth factor receptor 3 signaling regulates the onset of oligodendrocyte terminal differentiation. J Neurosci 23:883-94.

Oh LY, Yong VW 1996. Astrocytes promote process outgrowth by adult human oligodendrocytes in vitro through interaction between bFGF and astrocyte extracellular matrix. Glia 17:237-53.

Ohmachi S, Mikami T, Konishi M, Miyake A, Itoh N 2003. Preferential neurotrophic activity of fibroblast growth factor-20 for dopaminergic neurons through fibroblast growth factor receptor-1c. J Neurosci Res 72:436-43.

Okajima K, Robinson LK, Hart MA, Abuelo DN, Cowan LS, Hasegawa T, Maumenee IH, Wang Jabs E 1999. Ocular anterior chamber dysgenesis in craniosynostosis syndromes with a fibroblast growth factor receptor 2 mutation. Am J Med Genet 85:160-70.

Olwin BB, Hauschka SD, Neufeld G, Gospodarowicz D 1986. Identification of the fibroblast growth factor receptor of Swiss 3T3 cells and mouse skeletal muscle myoblasts. Biochemistry 25:3487-92. 
Ong SH, Hadari YR, Gotoh N, Guy GR, Schlessinger J, Lax I 2001. Stimulation of phosphatidylinositol 3-kinase by fibroblast growth factor receptors is mediated by coordinated recruitment of multiple docking proteins. Proc Natl Acad Sci U S A 98:6074-9.

Orioli IM, Castilla EE, Barbosa-Neto JG 1986. The birth prevalence rates for the skeletal dysplasias. J Med Genet 23:328-32.

Ornitz DM 2000. FGFs, heparan sulfate and FGFRs: complex interactions essential for development. Bioessays 22:108-12.

Ornitz DM, Itoh $\mathrm{N}$ 2001. Fibroblast growth factors. Genome Biol 2:REVIEWS3005.

Orr-Urtreger A, Bedford MT, Burakova T, Arman E, Zimmer Y, Yayon A, Givol D, Lonai P 1993. Developmental localization of the splicing alternatives of fibroblast growth factor receptor-2 (FGFR2). Dev Biol 158:475-86.

Orr-Urtreger A, Givol D, Yayon A, Yarden Y, Lonai P 1991. Developmental expression of two murine fibroblast growth factor receptors, flg and bek. Development 113:1419-34.

Pebusque MJ, Chaffanet M, Popovici C, Birnbaum D 2000. FGFR1 and MOZ, two key genes involved in malignant hemopathies linked to rearrangements within the chromosomal region 8p11-12. Bull Cancer 87:887-94.

Peng H, Moffett J, Myers J, Fang X, Stachowiak EK, Maher P, Kratz E, Hines J, Fluharty SJ, Mizukoshi E, Bloom DC, Stachowiak MK 2001. Novel nuclear signaling pathway mediates activation of fibroblast growth factor-2 gene by type 1 and type 2 angiotensin II receptors. Mol Biol Cell 12:449-62.

Peters KG, Werner S, Chen G, Williams LT 1992. Two FGF receptor genes are differentially expressed in epithelial and mesenchymal tissues during limb formation and organogenesis in the mouse. Development 114:233-43.

Pickles JO 2001. The expression of fibroblast growth factors and their receptors in the embryonic and neonatal mouse inner ear. Hear Res 155:54-62.

Pickles JO, Chir B 2002. Roles of fibroblast growth factors in the inner ear. Audiol Neurootol 7:36-9.

Pickles JO, Harter C, Rebillard G 1998. Fibroblast growth factor receptor expression in outer hair cells of rat cochlea. Neuroreport 9:4093-5.

Pirvola U, Spencer-Dene B, Xing-Qun L, Kettunen P, Thesleff I, Fritzsch B, Dickson C, Ylikoski J 2000. FGF/FGFR-2(IIIb) signaling is essential for inner ear morphogenesis. J Neurosci 20:6125-34. 
Pirvola U, Ylikoski J, Trokovic R, Hebert JM, McConnell SK, Partanen J 2002. FGFR1 is required for the development of the auditory sensory epithelium. Neuron 35:671-80.

Plath A, Einspanier R, Gabler C, Peters F, Sinowatz F, Gospodarowicz D, Schams D 1998. Expression and localization of members of the fibroblast growth factor family in the bovine mammary gland. J Dairy Sci 81:2604-13.

Plotnikov AN, Hubbard SR, Schlessinger J, Mohammadi M 2000. Crystal structures of two FGF-FGFR complexes reveal the determinants of ligandreceptor specificity. Cell 101:413-24.

Pringle NP, Yu WP, Howell M, Colvin JS, Ornitz DM, Richardson WD 2003. Fgfr3 expression by astrocytes and their precursors: evidence that astrocytes and oligodendrocytes originate in distinct neuroepithelial domains. Development 130:93-102.

Reilly JF, Maher PA 2001. Importin beta-mediated nuclear import of fibroblast growth factor receptor: role in cell proliferation. J Cell Biol 152:1307-12.

Renier D, Lajeunie E, Arnaud E, Marchac D 2000. Management of craniosynostoses. Childs Nerv Syst 16:645-58.

Revest JM, Spencer-Dene B, Kerr K, De Moerlooze L, Rosewell I, Dickson C 2001. Fibroblast Growth Factor Receptor 2-IIIb Acts Upstream of Shh and Fgf4 and Is Required for Limb Bud Maintenance but Not for the Induction of Fgf8, Fgf10, Msx1, or Bmp4. Dev Biol 231:47-62.

Richelda R, Ronchetti D, Baldini L, Cro L, Viggiano L, Marzella R, Rocchi M, Otsuki T, Lombardi L, Maiolo AT, Neri A 1997. A novel chromosomal translocation $\mathrm{t}(4 ; 14)(\mathrm{p} 16.3 ; \mathrm{q} 32)$ in multiple myeloma involves the fibroblast growth-factor receptor 3 gene. Blood 90:4062-70.

Ristow HJ, Messmer TO 1988. Basic fibroblast growth factor and insulin-like growth factor I are strong mitogens for cultured mouse keratinocytes. J Cell Physiol 137:277-84.

Rousseau F, Bonaventure J, Le Merrer M, Maroteaux P, Munnich A 1996. Mutations of FGFR3 gene cause 3 types of nanisms with variably severity: achondroplasia, thanatophoric nanism and hypochondroplasia. Ann Endocrinol (Paris) 57:153.

Rousseau F, Bonaventure J, Le Merrer M, Munnich A 1996. Association of achondroplasia to a mutation in the transmembrane domain of fibroblastic growth factor receptor 3 (FGFR3). Ann Endocrinol (Paris) 57:151-2.

Rousseau F, Bonaventure J, Legeai-Mallet L, Pelet A, Rozet JM, Maroteaux P, Le Merrer M, Munnich A 1994. Mutations in the gene encoding fibroblast growth factor receptor-3 in achondroplasia. Nature 371:252-4. 
Rousseau F, Bonaventure J, Legeai-Mallet L, Pelet A, Rozet JM, Maroteaux P, Le Merrer M, Munnich A 1996. Mutations of the fibroblast growth factor receptor-3 gene in achondroplasia. Horm Res 45:108-10.

Rousseau F, Bonaventure J, Legeai-Mallet L, Schmidt H, Weissenbach J, Maroteaux P, Munnich A, Le Merrer M 1996. Clinical and genetic heterogeneity of hypochondroplasia. J Med Genet 33:749-52.

Rousseau F, el Ghouzzi V, Delezoide AL, Legeai-Mallet L, Le Merrer M, Munnich A, Bonaventure J 1996. Missense FGFR3 mutations create cysteine residues in thanatophoric dwarfism type I (TD1). Hum Mol Genet 5:509-12.

Rousseau F, Saugier P, Le Merrer M, Munnich A, Delezoide AL, Maroteaux P, Bonaventure J, Narcy F, Sanak M 1995. Stop codon FGFR3 mutations in thanatophoric dwarfism type 1. Nat Genet 10:11-2.

Sahni M, Ambrosetti DC, Mansukhani A, Gertner R, Levy D, Basilico C 1999. FGF signaling inhibits chondrocyte proliferation and regulates bone development through the STAT-1 pathway. Genes Dev 13:1361-6.

Sahni M, Raz R, Coffin JD, Levy D, Basilico C 2001. STAT1 mediates the increased apoptosis and reduced chondrocyte proliferation in mice overexpressing FGF2. Development 128:2119-29.

Saxton TM, Ciruna BG, Holmyard D, Kulkarni S, Harpal K, Rossant J, Pawson T 2000. The SH2 tyrosine phosphatase shp2 is required for mammalian limb development. Nat Genet 24:420-3.

Schlessinger J, Plotnikov AN, Ibrahimi OA, Eliseenkova AV, Yeh BK, Yayon A, Linhardt RJ, Mohammadi M 2000. Crystal structure of a ternary FGF-FGFRheparin complex reveals a dual role for heparin in FGFR binding and dimerization. Mol Cell 6:743-50.

Shiang R, Thompson LM, Zhu YZ, Church DM, Fielder TJ, Bocian M, Winokur ST, Wasmuth JJ 1994. Mutations in the transmembrane domain of FGFR3 cause the most common genetic form of dwarfism, achondroplasia. Cell 78:335-42.

Sleeman M, Fraser J, McDonald M, Yuan S, White D, Grandison P, Kumble K, Watson JD, Murison JG, Kim I, Moon S, Yu K, Kim U, Koh GY 2001. Identification of a new fibroblast growth factor receptor, FGFR5

A novel fibroblast growth factor receptor-5 preferentially expressed in the pancreas(1). Gene 271:171-82.

Smedley D, Demiroglu A, Abdul-Rauf M, Heath C, Cooper C, Shipley J, Cross NC 1999. ANF198-FGFR1 transforms Ba/F3 cells to growth factor independence and results in high level tyrosine phosphorylation of STATS 1 and 5. Neoplasia 1:349-55. 
St-Jacques B, Hammerschmidt M, McMahon AP 1999. Indian hedgehog signaling regulates proliferation and differentiation of chondrocytes and is essential for bone formation. Genes Dev 13:2072-86.

Stachowiak EK, Maher PA, Tucholski J, Mordechai E, Joy A, Moffett J, Coons S, Stachowiak MK 1997. Nuclear accumulation of fibroblast growth factor receptors in human glial cells--association with cell proliferation. Oncogene 14:2201-11.

Stachowiak MK, Maher PA, Joy A, Mordechai E, Stachowiak EK 1996. Nuclear accumulation of fibroblast growth factor receptors is regulated by multiple signals in adrenal medullary cells. Mol Biol Cell 7:1299-317.

Stachowiak MK, Maher PA, Joy A, Mordechai E, Stachowiak EK 1996. Nuclear localization of functional FGF receptor 1 in human astrocytes suggests a novel mechanism for growth factor action. Brain Res Mol Brain Res 38:161-5.

Stauber DJ, DiGabriele AD, Hendrickson WA 2000. Structural interactions of fibroblast growth factor receptor with its ligands. Proc Natl Acad Sci U S A 97:4954.

Su WC, Kitagawa M, Xue N, Xie B, Garofalo S, Cho J, Deng C, Horton WA, Fu $X Y$ 1997. Activation of Stat1 by mutant fibroblast growth-factor receptor in thanatophoric dysplasia type II dwarfism. Nature 386:288-92.

Suhardja A, Hoffman $\mathrm{H}$ 2003. Role of growth factors and their receptors in proliferation of microvascular endothelial cells. Microsc Res Tech 60:70-5.

Sulpice E, Bryckaert M, Lacour J, Contreres JO, Tobelem G 2002. Platelet factor 4 inhibits FGF2-induced endothelial cell proliferation via the extracellular signalregulated kinase pathway but not by the phosphatidylinositol 3-kinase pathway. Blood 100:3087-94.

Superti-Furga A, Eich G, Bucher HU, Wisser J, Giedion A, Gitzelmann R, Steinmann B 1995. A glycine 375-to-cysteine substitution in the transmembrane domain of the fibroblast growth factor receptor-3 in a newborn with achondroplasia. Eur J Pediatr 154:215-9.

Tavormina PL, Bellus GA, Webster MK, Bamshad MJ, Fraley AE, McIntosh I, Szabo J, Jiang W, Jabs EW, Wilcox WR, Wasmuth JJ, Donoghue DJ, Thompson LM, Francomano CA 1999. A novel skeletal dysplasia with developmental delay and acanthosis nigricans is caused by a Lys650Met mutation in the fibroblast growth factor receptor 3 gene. Am J Hum Genet 64:722-31.

Tavormina PL, Shiang R, Thompson LM, Zhu YZ, Wilkin DJ, Lachman RS, Wilcox WR, Rimoin DL, Cohn DH, Wasmuth JJ 1995. Thanatophoric dysplasia (types I and II) caused by distinct mutations in fibroblast growth factor receptor 3. Nat Genet 9:321-8.

Tickle C, Munsterberg A 2001. Vertebrate limb development--the early stages in 
chick and mouse. Curr Opin Genet Dev 11:476-81.

Trokovic R, Trokovic N, Hernesniemi S, Pirvola U, Vogt Weisenhorn DM, Rossant J, McMahon AP, Wurst W, Partanen J 2003. FGFR1 is independently required in both developing mid- and hindbrain for sustained response to isthmic signals. Embo J 22:1811-23.

Ullrich A, Schlessinger J 1990. Signal transduction by receptors with tyrosine kinase activity. Cell 61:203-12.

van Rhijn BW, Montironi R, Zwarthoff EC, Jobsis AC, van der Kwast TH 2002. Frequent FGFR3 mutations in urothelial papilloma. J Pathol 198:245-51.

van Rhijn BW, van Tilborg AA, Lurkin I, Bonaventure J, de Vries A, Thiery JP, van der Kwast TH, Zwarthoff EC, Radvanyi F 2002. Novel fibroblast growth factor receptor 3 (FGFR3) mutations in bladder cancer previously identified in non-lethal skeletal disorders. Eur J Hum Genet 10:819-24.

Vortkamp A, Lee K, Lanske B, Segre GV, Kronenberg HM, Tabin CJ 1996. Regulation of rate of cartilage differentiation by Indian hedgehog and PTHrelated protein. Science 273:613-22.

Walshe J, Mason I 2000. Expression of FGFR1, FGFR2 and FGFR3 during early neural development in the chick embryo. Mech Dev 90:103-10.

Wang Y, Spatz MK, Kannan K, Hayk H, Avivi A, Gorivodsky M, Pines M, Yayon A, Lonai P, Givol D 1999. A mouse model for achondroplasia produced by targeting fibroblast growth factor receptor 3. Proc Natl Acad Sci U S A 96:445560 .

Weinstein M, Xu X, Ohyama K, Deng CX 1998. FGFR-3 and FGFR-4 function cooperatively to direct alveogenesis in the murine lung. Development 125:361523.

Welm BE, Freeman KW, Chen M, Contreras A, Spencer DM, Rosen JM 2002. Inducible dimerization of FGFR1: development of a mouse model to analyze progressive transformation of the mammary gland. J Cell Biol 157:703-14.

Werner S, Duan DS, de VC, Peters KG, Johnson DE, Williams LT 1992. Differential splicing in the extracellular region of fibroblast growth factor receptor 1 generates receptor variants with different ligand-binding specificities. Molecular \& Cellular Biology 12:82-8.

Werner S, Weinberg W, Liao X, Peters KG, Blessing M, Yuspa SH, Weiner RL, Williams LT 1993. Targeted expression of a dominant-negative FGF receptor mutant in the epidermis of transgenic mice reveals a role of FGF in keratinocyte organization and differentiation. Embo J 12:2635-43.

Wiedlocha A, Falnes PO, Madshus IH, Sandvig K, Olsnes S 1994. Dual mode of 
signal transduction by externally added acidic fibroblast growth factor. Cell 76:1039-51.

Wiedlocha A, Falnes PO, Rapak A, Klingenberg O, Munoz R, Olsnes S 1995. Translocation of cytosol of exogenous, CAAX-tagged acidic fibroblast growth factor. J Biol Chem 270:30680-5.

Xiao G, Jiang D, Gopalakrishnan R, Franceschi RT 2002. Fibroblast growth factor 2 induction of the osteocalcin gene requires MAPK activity and phosphorylation of the osteoblast transcription factor, Cbfa1/Runx2. J Biol Chem 277:36181-7.

Xu H, Goldfarb M 2001. Multiple effector domains within SNT1 coordinate ERK activation and neuronal differentiation of PC12 cells. J Biol Chem 276:13049-56.

Xu H, Lee KW, Goldfarb M 1998. Novel recognition motif on fibroblast growth factor receptor mediates direct association and activation of SNT adapter proteins. J Biol Chem 273:17987-90.

Xu X, Li C, Takahashi K, Slavkin HC, Shum L, Deng CX 1999. Murine fibroblast growth factor receptor 1alpha isoforms mediate node regression and are essential for posterior mesoderm development. Dev Biol 208:293-306.

Xu X, Qiao W, Li C, Deng CX 2002. Generation of Fgfr1 conditional knockout mice. Genesis 32:85-6.

Xu X, Weinstein M, Li C, Deng CX 1999. Fibroblast growth factor receptors (FGFRs) and their roles in limb development. Cell \& Tissue Research 296:33-43.

Xu X, Weinstein M, Li C, Naski M, Cohen RI, Ornitz DM, Leder P, Deng C 1998. Fibroblast growth factor receptor 2 (FGFR2)-mediated reciprocal regulation loop between FGF8 and FGF10 is essential for limb induction. Development 125:75365 .

Yamaguchi TP, Harpal K, Henkemeyer M, Rossant J 1994. fgfr-1 is required for embryonic growth and mesodermal patterning during mouse gastrulation. Genes Dev 8:3032-44.

Yu C, Wang F, Jin C, Wu X, Chan WK, McKeehan WL 2002. Increased carbon tetrachloride-induced liver injury and fibrosis in FGFR4-deficient mice. Am J Pathol 161:2003-10.

Yu C, Wang F, Kan M, Jin C, Jones RB, Weinstein M, Deng CX, McKeehan WL 2000. Elevated cholesterol metabolism and bile acid synthesis in mice lacking membrane tyrosine kinase receptor FGFR4. J Biol Chem 275:15482-9.

Yu K, Herr AB, Waksman G, Ornitz DM 2000. Loss of fibroblast growth factor receptor 2 ligand-binding specificity in apert syndrome. Proc Natl Acad Sci U S A 97:14536-41. 
Yu K, Xu J, Liu Z, Sosic D, Shao J, Olson EN, Towler DA, Ornitz DM 2003. Conditional inactivation of FGF receptor 2 reveals an essential role for FGF signaling in the regulation of osteoblast function and bone growth. Development 130:3063-3074.

Zhou YX, Xu X, Chen L, Li C, Brodie SG, Deng CX 2000. A Pro250Arg substitution in mouse Fgfr1 causes increased expression of Cbfa1 and premature fusion of calvarial sutures. Hum Mol Genet 9:2001-8. 
Table 1. Targeted mutation of Fgfrs in mouse

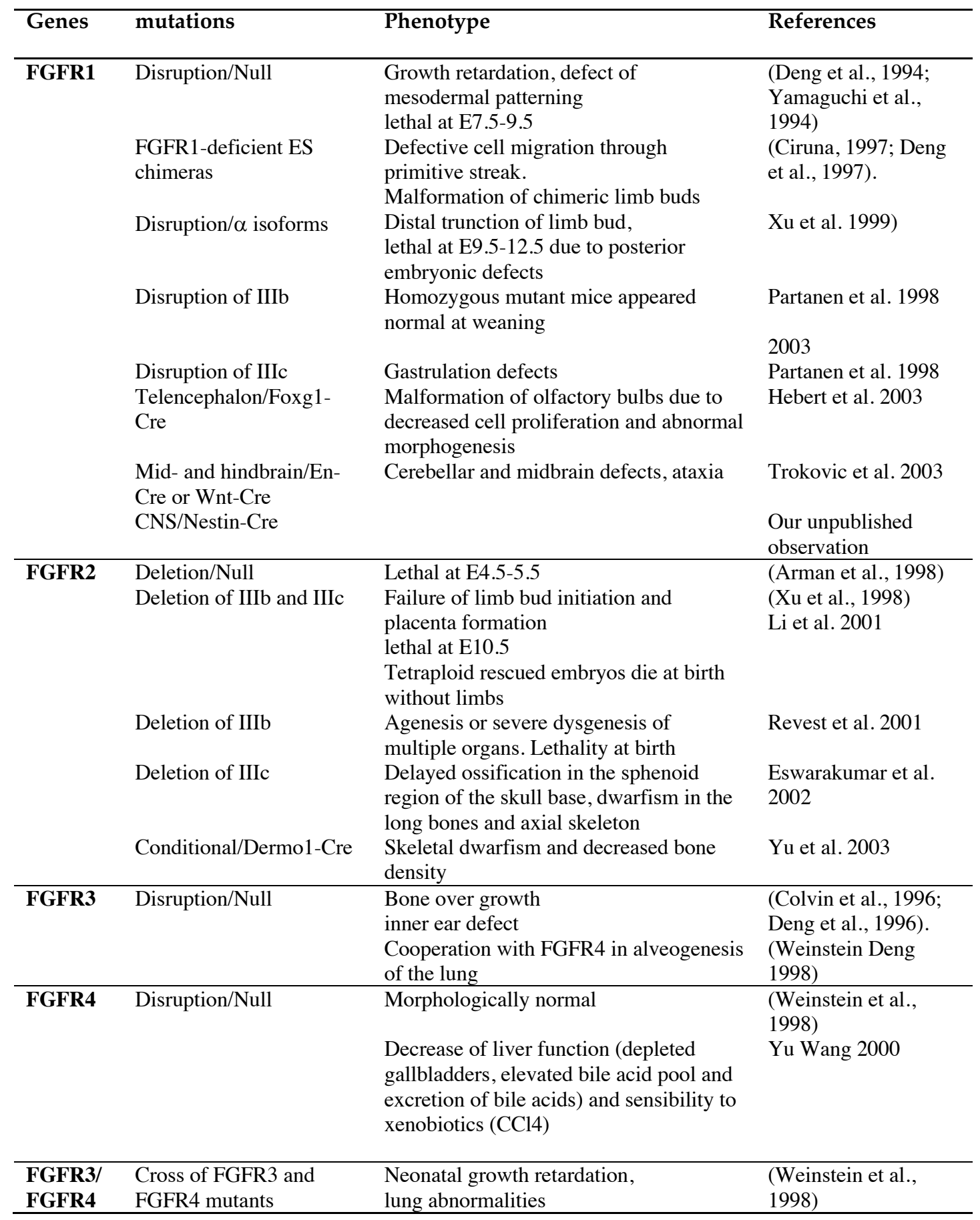


Table 2: FGFR-related skeletal syndromes, phenotypes and their corresponding mutations

\begin{tabular}{|c|c|c|}
\hline Syndromes & Genes and mutations & Phenotypes \\
\hline $\begin{array}{l}\text { Major defects: flat bone } \\
\text { abnormalities }\end{array}$ & Fgfr1, Fgfr2, Fgfr3 & $\begin{array}{l}\text { Common features: autosomal dominant craniosynostosis } \\
\text { (prenamture fusion of the cranial sutures), tower-shaped skull, } \\
\text { spaced protruding eyes, beaked nose, underdevelopped midface }\end{array}$ \\
\hline Antley-Bixler-like (ABS) & $\begin{array}{l}\text { Fgfr2/lgllla: Y290C } \\
\text { Fgfr2/lglllc: S351C }\end{array}$ & $\begin{array}{l}\text { Craniofacial and limb abnormalities (no dermatologic } \\
\text { abnormalities) }\end{array}$ \\
\hline Apert syndrome (AS) & $\begin{array}{l}\text { Fgfr2/lgllla: S252W, P253 } \\
\text { De novo insertion of Alu elements is } \\
\text { observed. }\end{array}$ & $\begin{array}{l}\text { Severe syndyctaly (cutaneous and bony fusion of the digits). } \\
\text { Broad thumbs broad great toes (due to an increase number of } \\
\text { precursor cells). Wild midline calvarial defect. }\end{array}$ \\
\hline $\begin{array}{l}\text { Beare-Stevenson cutis } \\
\text { gyrata (BSS) }\end{array}$ & $\begin{array}{l}\text { Fgfr2/TM: Y375C } \\
\text { Fgfr2/linker Iglll-TM: S372C }\end{array}$ & $\begin{array}{l}\text { Cutis gyrata or furrowed (overgrowth) skin with a corrugated } \\
\text { appearance and acanthosis nigricans. Digits abnormalities. }\end{array}$ \\
\hline $\begin{array}{l}\text { Crouzon and } \\
\text { Acanthosis Nigricans } \\
\text { syndrome (CAN) }\end{array}$ & $\begin{array}{l}\text { Fgfr2/Igllla: S267P, C278F, W289G, } \\
\text { Y290G, HIQ287-289, T268-TG } \\
\text { Fgfr2/Iglllc: Y328C, G338R, Y340H, } \\
\text { C342Y,W, R, F or S, A344G or A, S347C, } \\
\text { S354C } \\
\text { Fgfr3/TM: A391E, P250R }\end{array}$ & Normal hands and feet \\
\hline $\begin{array}{l}\text { Jackson-Weiss } \\
\text { syndrome (JWS) }\end{array}$ & Fgfr2/lglllc: A344G, C342S or R & Hands are usually normal. Foot abnormalities. \\
\hline Muenke syndrome (MS) & Fgfr3/lgllla: P250R & $\begin{array}{l}\text { Abnormalities of hands and feet (thimble-like middle phalanges, } \\
\text { coned epiphyses, and carpal and tarsal fusions). }\end{array}$ \\
\hline $\begin{array}{l}\text { Non-syn unilateral } \\
\text { coronal synostosis }\end{array}$ & Fgfr3/lgllla: P250R & Variable, with or without craniosynostosis \\
\hline Pfeiffer syndrome (PS) & $\begin{array}{l}\text { Fgfr1/Igllla: P252R } \\
\text { Fgfr2: A314S, D321A, T341P, C342R, W, } \\
\text { Y or S (Iglllc), V359F } \\
\text { Fgfr3/lgllla: P250R }\end{array}$ & $\begin{array}{l}\text { Short fingers and soft-tissue syndactyly (due to increase } \\
\text { expression of KGFR) }\end{array}$ \\
\hline $\begin{array}{l}\text { Saethre-Chotzen-like } \\
\text { syndrome(SCS) }\end{array}$ & $\begin{array}{l}\text { Fgfr2/Igllla: VV269-70del } \\
\text { Fgfr3/Igllla: P250R }\end{array}$ & Craniofacial and limb abnormalities \\
\hline
\end{tabular}




\begin{tabular}{|l|l|l|}
\hline Syndromes & Genes and mutations & Phenotypes \\
\hline $\begin{array}{l}\text { Major defects: long } \\
\text { bone abnormalities }\end{array}$ & Fgfr3 & $\begin{array}{l}\text { Common features: autosomal dominant, reduced height of } \\
\text { vertebral bodies and shortening of limbs. Poor cellular } \\
\text { proliferation of growth plate chondrocytes. }\end{array}$ \\
\hline Achondroplasia (ACH) & Fgfr3/TM: G346E, G375C, G380R & $\begin{array}{l}\text { Rhizomelic dwarfism (most pronounced in the proximal portion } \\
\text { of the limbs), relative macroencephaly, exaggerated lumbar } \\
\text { lordosis. Homozygotes ressemble TD patients (see below) }\end{array}$ \\
\hline $\begin{array}{l}\text { Severe achondroplasia } \\
\text { with developmental } \\
\text { delay \& acanthosis } \\
\text { nigricans (SADDAN) }\end{array}$ & Fgfr3/TKII: K650M & $\begin{array}{l}\text { Acanthosis nigricans, developmental delay, Craniofacial and limb } \\
\text { abnormalities }\end{array}$ \\
\hline $\begin{array}{l}\text { Thanatophoric } \\
\text { dysplasia (TDI or TDII) }\end{array}$ & $\begin{array}{l}\text { TDI: Fgfr3/Linkers bet Igll-lglll or IgllI-TM: } \\
\text { R248C, S249C, S371C, Stop807Gly, } \\
\text { Stop807Arg, Stop 807Cys } \\
\text { TDII: Fgfr3/TKII: K650E, A391E }\end{array}$ & $\begin{array}{l}\text { Most severe and lethal neonatal skeletal dysplasia } \\
\text { TDI: curved, short femurs with or without cloverleaf skull } \\
\text { TDII: straight, relatively long femurs and severe cloverleaf skull }\end{array}$ \\
\hline $\begin{array}{l}\text { Hypochondroplasia } \\
\text { (HCH) }\end{array}$ & Fgfr3/TKI: N540K & Similar to but midler than those of ACH and TD \\
\hline
\end{tabular}

Lewanda 1996, Muenke 1994 \& 1995, Bellus 1996, Lewanda 1996, Nagase 1998, Addor 1997, Tartaglia 1997, Przylepa 1996, Wilkie 1995, Briner 1991, Orlow 92, Slaney 1996, Lajeunie 1999, Von Gernet 2000, Oldridge 1999, Paznekas 1998, Schaefer 1998, Okajima 1999, Reardon 2000, Tsai 2001, Rutland 1995, Plomp 1998, Hollway 1998, Tavormina 1995, Meyers 1995, Rousseau 1995, Wilcox 1998 


\begin{tabular}{|c|c|c|c|}
\hline Syndromes & Frequency & $\begin{array}{l}\text { Genes and } \\
\text { mutations }\end{array}$ & Phenotypes \\
\hline Major defects: flat bone abnormalities & - & Fgfr1, Fgfr2, Fgfr3 & $\begin{array}{l}\text { Common features: autosomal dominant craniosynostosis } \\
\text { (prenamture fusion of the cranial sutures), tower-shaped } \\
\text { skull, widely spaced protruding eyes, beaked nose, } \\
\text { underdevelopped midface }\end{array}$ \\
\hline Antley-Bixler-like (ABS) & & $\begin{array}{l}\text { Fgfr2/lgllla: Y290C } \\
\text { Fgfr2/Igllic: S351C }\end{array}$ & $\begin{array}{l}\text { Craniofacial and limb abnormalities (no dermatologic } \\
\text { abnormalities) }\end{array}$ \\
\hline Apert syndrome (AS) & $1 / 65,000$ & \begin{tabular}{|l|} 
Fgfr2/Igllla: S252W, P253 . \\
Constitutive activated receptors. \\
De novo insertion of Alu elements \\
is observed.
\end{tabular} & $\begin{array}{l}\text { Severe syndyctaly (cutaneous and bony fusion of the } \\
\text { digits) associated with an increase in KGFR expression. } \\
\text { Broad thumbs broad great toes (due to an increase } \\
\text { number of precursor cells). Wild midline calvarial defect. } \\
\text { Cranio-facial abnormalities. }\end{array}$ \\
\hline Beare-Stevenson cutis gyrata (BSS) & & $\begin{array}{l}\text { Fgfr2/TM: Y375C (Transmembrane } \\
\text { dom) } \\
\text { Fgfr2/inker Igll-TM: S372C }\end{array}$ & $\begin{array}{l}\text { Cutis gyrata or furrowed (overgrowth) skin with a } \\
\text { corrugated appearance and acanthosis nigricans. Digits } \\
\text { abnormalities. Severe craniosynostosis }\end{array}$ \\
\hline Crouzon and Acanthosis Nigricans syndrome (CAN) & $1 / 50,000$ & $\begin{array}{l}\text { Fgfr2/Igllla: S267P, C278F, W289G, } \\
\text { Y290G, HIQ287-289 ( } 3 \text { aa } \\
\text { deletion), T268-TG ( } 1 \text { aa } \\
\text { insertion) } \\
\text { Fgfr2/Aglllc: Y328C, G338R, Y340H, } \\
\text { C342Y, C342W, C342R, C342F, } \\
\text { C342S, A344G, S347C, S354C, } \\
\text { A344A (creating donor splice site, } \\
\text { resulting in } 17 \text { amino acid } \\
\text { deletion), } \\
\text { Fgfr3/TM: A391E ((Lewanda } \\
\text { 1996), also in some ACH), P250R }\end{array}$ & Normal hands and feet \\
\hline Jackson-Weiss syndrome (JWS) & & Fgfr2/IIllle: A344G, C342S, C342R & Hands are usually normal. Foot abnormalities. \\
\hline Muenke syndrome (MS) & & Fgfr3/gl|lla: P250R & $\begin{array}{l}\text { Abnormalities of hands and feet (thimble-like middle } \\
\text { phalanges, coned epiphyses, and carpal and tarsal } \\
\text { fusions). Brachydactyly was seen in some cases; no } \\
\text { significant syndactyly or deviation of the great toe. } \\
\text { Sensorineural hearing loss was present in some and } \\
\text { developmental delay was seen in a minority. }\end{array}$ \\
\hline Non-syn unilateral coronal synostosis & & Fgfr3/gllla: P250R & Variable, with or without craniosynostosis \\
\hline Pfeiffer syndrome (PS) & & \begin{tabular}{|l|} 
Fgfr1/Igllla: P252R \\
Fgfr2: A314S, D321A, T341P, \\
C342R, C342Y, C342W, C342S \\
(Iglllc), V359F (more than 10 \\
mutations in the acceptor site of \\
exon 10 leading to increase \\
expression of KGFR (exon 9)) \\
Fgfr3/lgllla: P250R
\end{tabular} & $\begin{array}{l}\text { Short fingers and soft-tissue syndactyly (due to increase } \\
\text { expression of KGFR) }\end{array}$ \\
\hline Saethre-Chotzen-like syndrome (SCS) & & $\begin{array}{l}\text { Fgfr2/Igllla: VV269-70del } \\
\text { Fgfr3/Iglla: P250R }\end{array}$ & $\begin{array}{l}\text { Craniofacial and limb abnormalities (no dermatologic } \\
\text { abnormalities) }\end{array}$ \\
\hline
\end{tabular}

\begin{tabular}{|c|c|c|c|}
\hline Major defects: long bone abnormalities & - & Fgfr3 & $\begin{array}{l}\text { Common features: autosomal dominant, reduced height } \\
\text { of vertebral bodies and shortening of limbs. Poor cellular } \\
\text { proliferation of growth plate chondrocytes. }\end{array}$ \\
\hline Achondroplasia ( $\mathrm{ACH}$ ) & $1 / 26,000$ & Fgfr3/TM: G346E, G375C, G380R & $\begin{array}{l}\text { Rhizomelic dwarfism (most pronounced in the proximal } \\
\text { portion of the limbs), relative macroencephaly, } \\
\text { exaggerated lumbar lordosis. Homozygotes ressemble TD } \\
\text { patients (see below) }\end{array}$ \\
\hline $\begin{array}{l}\text { Severe achondroplasia with developmental delay \& acanthosis nigricans } \\
\text { (SADDAN) }\end{array}$ & & Fgfr3/TKll: K650M & $\begin{array}{l}\text { Acanthosis nigricans, developmental delay, Craniofacial } \\
\text { and limb abnormalities }\end{array}$ \\
\hline Thanatophoric dysplasia (TDI or TDII) & $1 / 20,000$ & $\begin{array}{l}\text { TDI: Fgfr3/Linkers bet Igll-Iglll or } \\
\text { Igll1-TM: R248C, S249C, S371C } \\
\text { (create unpaired Cys residues), } \\
\text { Stop807Gly, Stop807Arg, Stop } \\
807 \text { Cys (addition of } 141 \text { amino } \\
\text { acids) } \\
\text { TDII: Fgfr3/TKIII: K650E, A391E }\end{array}$ & $\begin{array}{l}\text { Most severe and lethal neonatal skeletal dysplasia } \\
\text { TDI: curved, short femurs with or without cloverleaf skull } \\
\text { TDDll: straight, relatively long femurs and severe cloverlea } \\
\text { skull }\end{array}$ \\
\hline Hypochondroplasia $(\mathrm{HCH})$ & & Fgfr3/TKl: N540K & Similar to but midler than those of ACH and TD \\
\hline
\end{tabular}

Lewanda 1996, Muenke 1994 \& 1995, Bellus 1996, Lewanda 1996, Nagase 1998, Addor 1997, Tartaglia 1997, Pryylepa 1996, Wilkie 1995, Briner 1991, Orlow 92, Slaney 1996, Lajeunie 1999, Von Gernet 2000 2000. Tsai 2001, Rutlas 1998, Schaefer 1998, Okajima 1999, Reardon 1995, Meyers 1995, Rousseau 1995, Wilcox 1998 

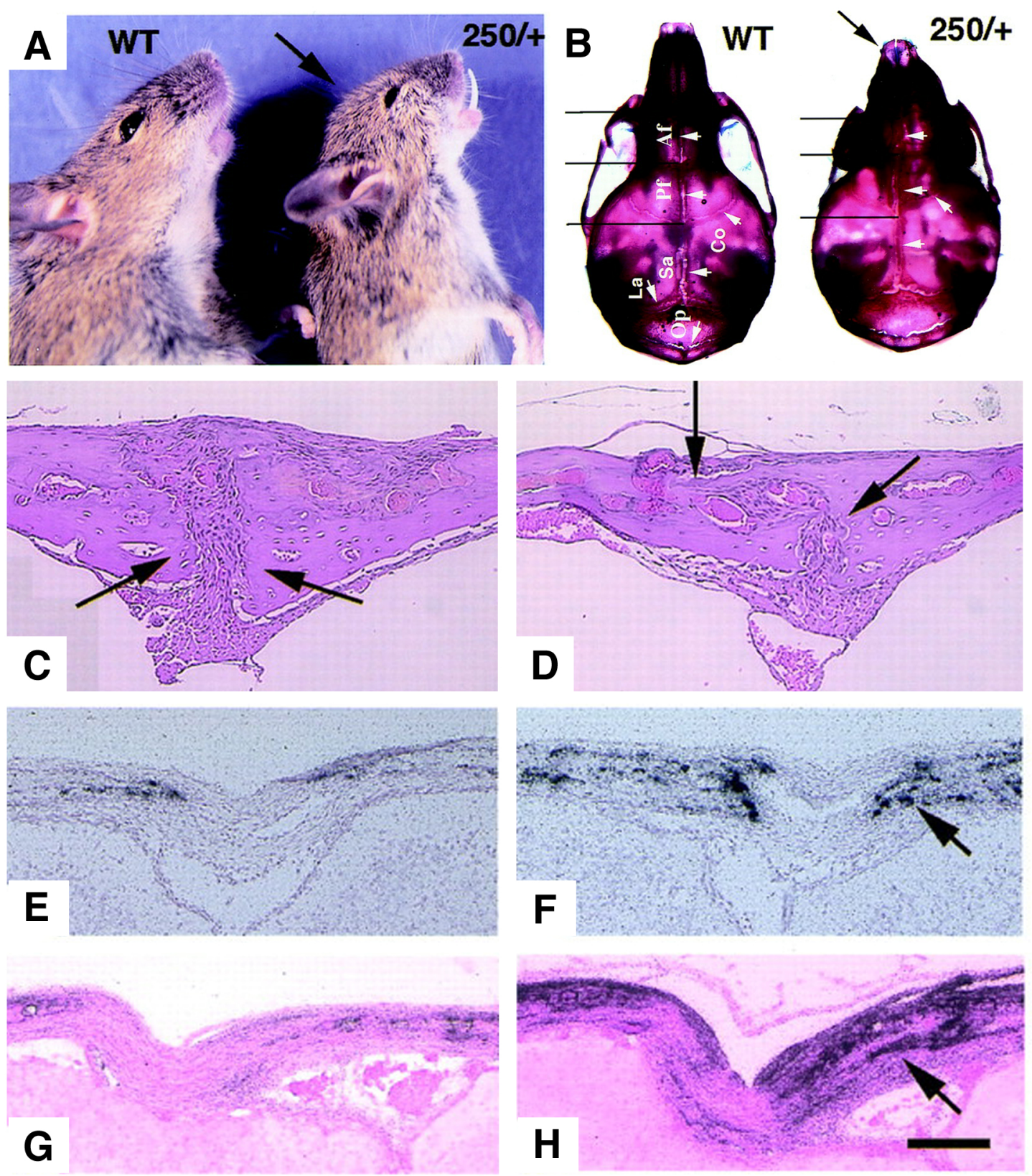


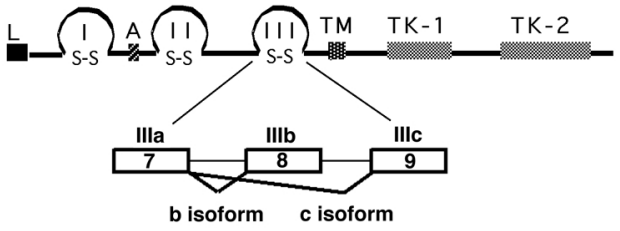




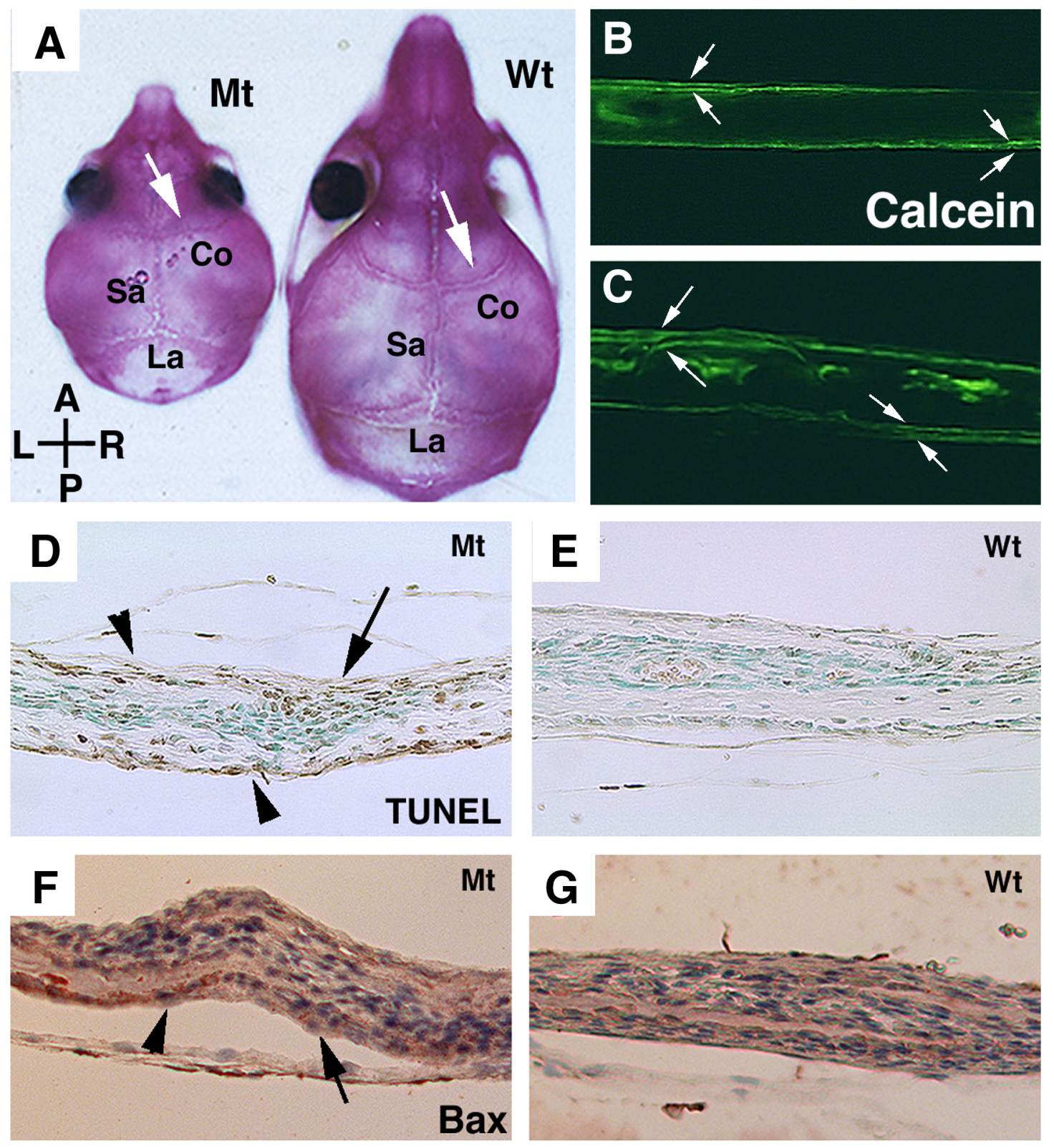




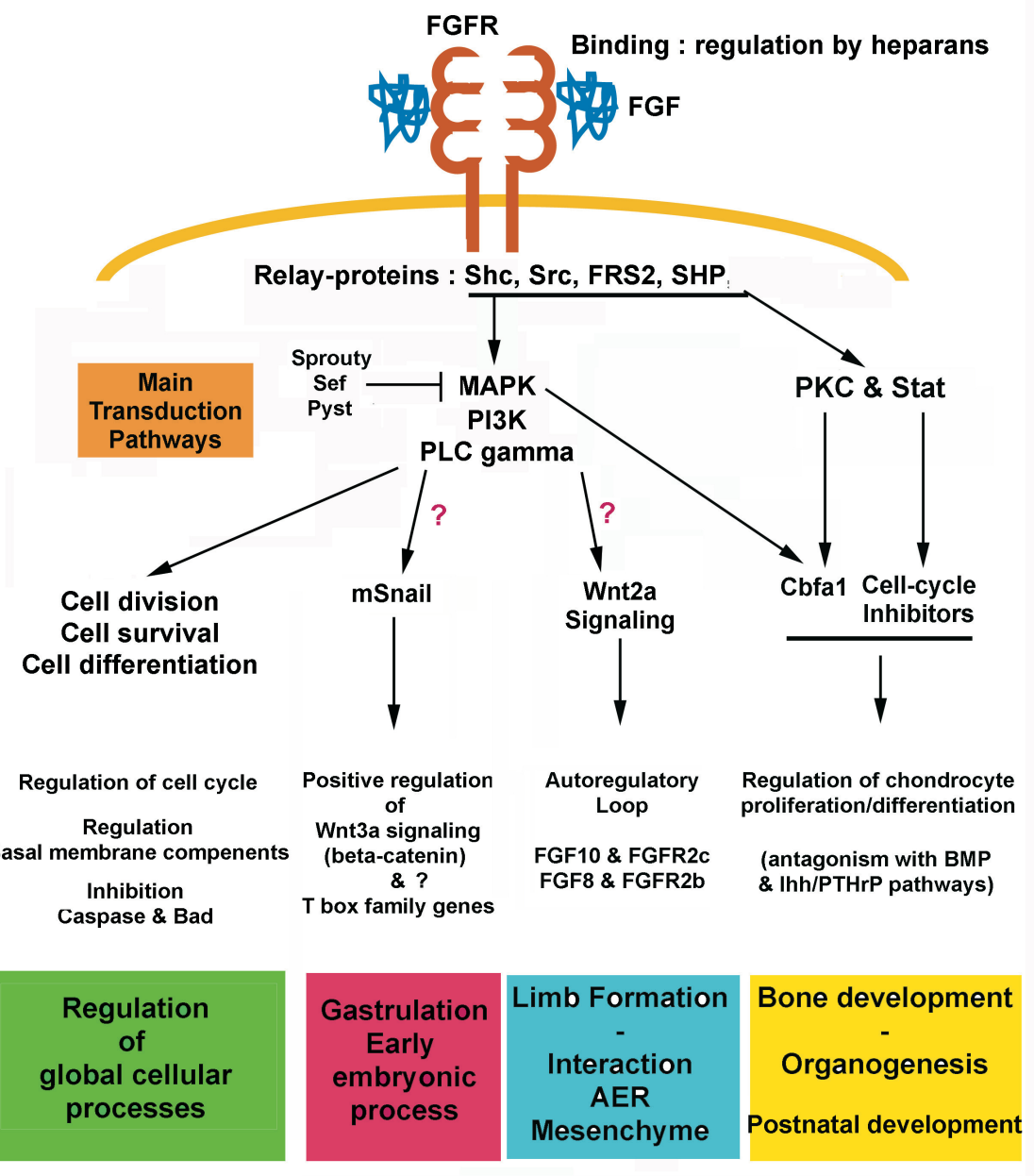

